\title{
SOFTWARE COPYRIGHT'S ORACLE FROM THE CLOUD
}

\author{
Lothar Determann ${ }^{\dagger}$ \& David Nimmer
}

\begin{abstract}
Clouds are on the horizon for software copyrights. The open source movement is actively trying to turn copyright into "copyleft." Courts around the world are reshaping the first sale doctrine, notably the European Court of Justice in UsedSoft v. Oracle not to mention the United States Court of Appeals for the Ninth Circuit in Autodesk v. Vernor. Software manufacturers are fleeing from distribution models toward service models-into the cloud. A perfect storm for software copyrights is brewing. The cloud promises to enable software publishers to place their code outside both the framework of copyright exhaustion under the first sale doctrine and the "distribution trigger" in open source code license terms. Users' inability, in the cloud context, to directly access the underlying software threatens to exert various side effects, notably affecting software interoperability. New kids on the block lose the ability to reverse engineer hosted software. Established platform providers gain the ability to prevent interoperability, based on laws prohibiting interference with computers and technical protection measures. These developments risk upsetting the delicate balance between exclusive rights for copyright owners and access privileges for the public-a balance that courts and legislatures have carefully established over the years-in order to foster creativity and innovation. With unprecedented pressure on traditional distribution models, how will copyright law cope? In our Article, we attempt to illuminate the immediate path ahead, discuss possible answers, and pose more questions.
\end{abstract}

(C) 2015 Lothar Determann and David Nimmer. Opinions expressed herein reflect only the authors' views, and should not be imputed to their universities, firms, clients, or others.

† Lothar Determann teaches computer, internet, and data privacy law at Freie Universität Berlin; University of California, Berkeley, School of Law; and Hastings College of the Law, San Francisco and practices technology law as a partner with Baker \& McKenzie LLP, admitted in California and Germany.

It David Nimmer teaches domestic and international copyright at the UCLA School of Law and as a guest at various other institutions. He has represented a wide array of clients in copyright matters at Irell \& Manella LLP. 


\section{Table of Contents}

I. INTRODUCTION 163

II. HISTORY AND APPLICATION OF COPYRIGHT PROTECTION FOR SOFTWARE. 165

A. CONFERRAL OF RightS ON COPYRIGHT PROPRIETORS .....................165

1. Titrating the appropriate amount of copyright protection .........................165

2. According protection to software's artistry, not its functionality ..............166

3. Computer Software Amendment of 1980 ............................................167

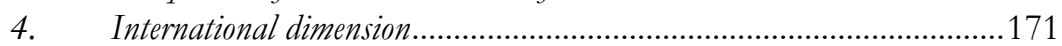

B. ReSERVATION OF Privileges TO SOFTWARE USERS.........................172

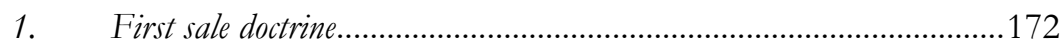

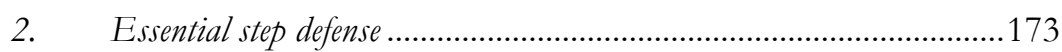

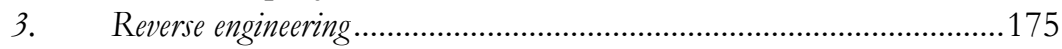

C. DiVERGENT INTERPRETATIONS OF SOFTWARE COPYRIGHT IN AND BETWEEN THE UNITED STATES AND THE

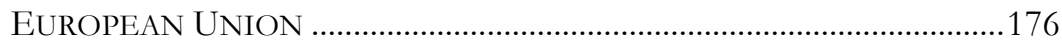

1. Starting in the United States...........................................................176

2. Moving to Europe............................................................................180

3. Cross-breezes: exceptions in United States and E.U. to the paradigms set forth above

a) Returning Stateside ..............................................................184

b) Final European Jaunt........................................................188

4. Departure from the statute's goals? .....................................................189

III. ECONOMICS AND TECHNOLOGY OF THE CLOUD ...................193

A. SOFTWARE COMMERCIALIZATION MODELS .........................................193

B. EXAMPLES OF CLOUD OFFERINGS ……………………………........195

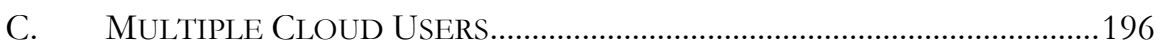

IV. THE CLOUD'S IMPACT ON SOFTWARE COPYRIGHTS ……......201

A. CHALLENGES TO COPYRIGHT LAW'S GOALS ..........................................201

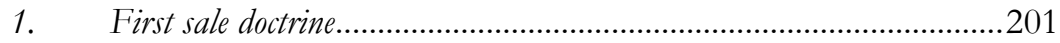

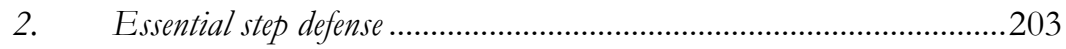

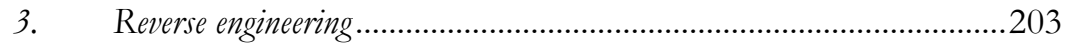

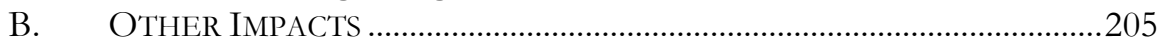

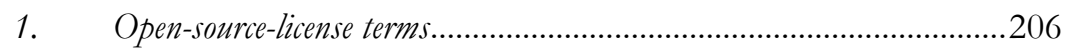

2. Unauthorized Access to Copyrighted Material.....................................206

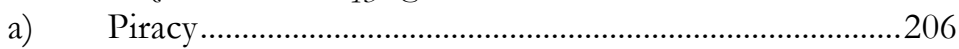

b) Facilitation of Multiple Cloud Users ...............................207

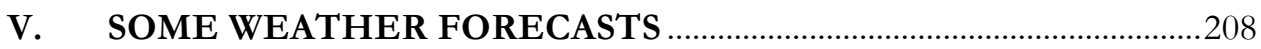



A. Gloomy Prospects: Dark Clouds Undermine the
GOALS OF 1980
B. A CHEERY REBUTTAL: RETURN TO AN EARLIER SENSIBILITY .........210
C. HighS AND LOWS IN TURBULENT TRANSITIONS 211

\section{INTRODUCTION}

It was never a happy marriage. Computer software and copyright law came from different families, embodied disparate values, pursued separate interests. So, even though the latter became the vehicle to secure legal protection for the former, the union was never smooth-even on the wedding day. At present, the plates are flying with ever more reckless abandon. As the open source movement has been active to turn copyright into "copyleft," courts around the world are reshaping the first sale doctrine, and software manufacturers are fleeing from distribution to service models, and most recently, into the cloud. With a perfect storm brewing, this Article steps in to offer some mild marital counseling.

Part of the initial bargain that brought software within the copyright fold was that users would obtain privileges in software via two legal devices- the "first sale" defense and the "essential step" doctrine. Yet, in recent years, software developers have striven to maximize their rights by enclosing their physical products with shrinkwrap or other purported contractual terms. Through that stratagem, they have sought to avoid the privileges that would otherwise inure to software users via the first sale doctrine. In that endeavor, they have largely achieved success within the United States, albeit not without some backlash. ${ }^{2}$ Yet, in UsedSoft v. Oracle, the European Court of Justice dealt Oracle and other software makers a blow in July 2012 by dramatically expanding the scope of "exhaustion," the European analog to the United States' first sale doctrine. ${ }^{3}$ Thus, the international status of these efforts is currently in flux. ${ }^{4}$ Moreover, even within those two jurisdictions, the results have been less than categorical-for instance, in March 2013, the United States Supreme Court held that copies made and first sold abroad can be imported into the United States against the U.S. copyright owner's will,

1. Lothar Determann, Dangerous Liaisons_Software Combinations as Derivative Works? Distribution, Installation, and Execution of Linked Programs Under Copyright Law, Commercial Licenses, and the GPL, 21 BERKELEY TECH. L.J. 1421, 1481 (2006).

2. See discussion infra Subsection II.C.1.

3. Case C-128/11, UsedSoft GmbH v. Oracle Int'l Corp., 2012 EUR-Lex CELEX, qণ 44-46 (July 3, 2012) (discussed infra Subsection II.C.2); see also GREGORY J. BATTERSBY ET AL., 2014 LICENSING UPDATE \$3.01, at 3-3 (2014).

4. See discussion infra Section IV.A 
potentially presaging a retreat from the expansive interpretation of "license" terms evident in prior opinions. ${ }^{5}$ Correlatively, more recent developments within Europe call into question the European Court of Justice ruling of 2012_-some portending its limitation, others its radical expansion. ${ }^{6}$

As if those developments were not dizzying enough in their own right, the advent of the cloud with service-based-as opposed to distributionbased-commercialization models ${ }^{7}$ injects even more volatility into the mix. By keeping software copies on their own servers and making software functionality available remotely as part of cloud offerings on a subscription basis, the cloud enables software publishers to place their code outside the framework of copyright exhaustion under both the first sale doctrine and the "distribution trigger" in open source code license terms. ${ }^{8}$ Users' inability, in the cloud context, to directly access the underlying software threatens to exert various side effects, notably affecting software interoperability, and new kids on the block lose the ability to reverse engineer hosted software.' Established platform providers gain the ability to prevent interoperability, based on laws prohibiting interference with computers and technical protection measures.

These developments risk upsetting the delicate balance between exclusive rights for copyright owners and access rights for the public, a balance that courts and legislatures have carefully established over the years in order to foster creativity and innovation. With unprecedented pressure on traditional distribution models, how will copyright law cope? Having no idea of the ultimate goal towards which the law is heading, we attempt to illuminate the immediate path ahead, in the light of past events that have brought matters to their current stance.

5. See Kirtsaeng v. John Wiley \& Sons, Inc., 133 S. Ct. 1351 (2013) (discussed infra Subsection II.C.3.a)).

6. See discussion infra Part II.C.3.b)

7. See infra Part III.

8. Most open source license terms allow running and using software without significant restrictions and apply license conditions only if and when the licensee starts distributing the code or modifications thereof; see, for example, Section $O$, paragraph 2 of the GPLv2, FreE SOFTwARE FOUNDATION (June 1991), http://www.gnu.org/licenses/gpl2.0.html; Lothar Determann, Stuart Pixley \& Gary Shapiro, Managing commercial risks in open source software licensing, J. INTELL. PROP. L \& PRAC., 2007, p. 1, 6.

9. Regarding interoperability, see discussion infra Subsection IV.A.3; regarding reverse engineering, see discussion infra Subsection II.B.3 


\section{HISTORY AND APPLICATION OF COPYRIGHT PROTECTION FOR SOFTWARE}

From the beginnings of computer technology, copyright law was an unlikely candidate to protect intellectual property in software. After all, copyright is intended, at base, to protect creative expression, such as paintings, music, novels, and sculptures. Yet the value in most software inheres not in its creative expression, but instead in its technical functionality - a matter that copyright law was never intended to protect. In fact, the United States Copyright Act expressly carves out ideas, procedures, processes, systems and methods of operation from its scope of protection. ${ }^{10}$

Nevertheless, copyright law ended up as the legal vehicle providing the primary source of intellectual property law protection for software. ${ }^{11}$ It took considerable bending and tweaking to make it work. ${ }^{12}$ Even the rise of open source licensing and "copyleft"13 can be viewed as an affirmation of software copyright law, insofar as copyleft and the broader trend of "sharing nicely" were enabled precisely through leveraging the adaptation right afforded to copyright owners - a feature that patent and trade secret laws pointedly do not offer. ${ }^{15}$

\section{A. Conferral of Rights on Copyright Proprietors}

\section{Titrating the appropriate amount of copyright protection}

As contemplated by the U.S. Constitution, ${ }^{16}$ the Copyright Act protects creative works through exclusive rights that encourage further creation and public availability of such works. ${ }^{17}$ Those exclusive rights enable owners to permit or prohibit reproductions and other exploitations of their works, ${ }^{18}$

10. 17 U.S.C. S 102(b) (2012).

11. See Peter S. Menell, Tailoring Legal Protection for Computer Software, 39 STAN. L. REV. 1329, 1354 (1987).

12. See id. at 1329; see also Mark A. Lemley, Convergence in the Law of Software Copyright?, 10 Berkeley TeCH. L.J. 1, 3-6 (1995); Pamela Samuelson et al., A Manifesto Concerning the Legal Protection of Computer Programs, 94 COLUM. L. REV. 2308 (1994).

13. Determann, supra note 1 , at 1481.

14. Yochai Benkler, Sharing Nicely: On Shareable Goods and the Emergence of Sharing as a Modality of Economic Production, 114 YALE L.J. 273, 334-36 (2004).

15. Determann, supra note 1 , at 1442.

16. U.S. CONST. art. I, $\int 8, \mathrm{cl} .8$ provides that Congress shall have the power " $[\mathrm{t}] \mathrm{o}$ promote the Progress of Science and useful Arts, by securing for limited Times to Authors and Inventors the exclusive Right to their respective Writings and Discoveries."

17. See Pamela Samuelson, Computer Programs, User Interfaces, and Section 102(b) of the Copyright Act of 1976: A Critique of Lotus v. Paperback, 55 LAW \& CONTEMP. ProBs. 311, 339 (1992).

18. The full roster of exclusive rights is contained in 17 U.S.C. \ 106 (2012). 
charging permission fees to utilize the work. The prospect of such license charges are intended to incentivize authors to create and to adapt original works.

But the public interest in creative works may be derogated by either under- or over-protection. ${ }^{19}$ If facts and functionality could be copyrighted by the first author who writes about them, for example, then later authors could not create their own creative works of authorship based on the same facts or functionality. If the first author who writes a book about an accounting method refuses to grant licenses, others could not write better books about the same method. ${ }^{20}$ On the other hand, if an author could not achieve some measure of protection against copying of her book about accounting methods, then perhaps no one would wish to expend the labor in the first place to write one. Accordingly, legislatures and courts have, over the years, endeavored to maintain a delicate balance ${ }^{21}$ between granting exclusive rights to authors and affording access privileges to the public. ${ }^{22}$

\section{According protection to software's artistry, not its functionality}

As the vector on which that balancing act is performed, the Copyright Act attentively limits copyrightable subject matter to creative, artistic expression by preserving underlying ideas and functionality in the public domain:

In no case does copyright protection for an original work of authorship extend to any idea, procedure, process, system, method of operation, concept, principle, or discovery, regardless of the form in which it is described, explained, illustrated, or embodied in such work. ${ }^{23}$

Historically speaking, this express exception made software particularly ill-suited for copyright protection-one need only consider that the value of

19. See Samuelson, supra note 17, at 338-40; see also Determann, supra note 1, at 1438.

20. See Baker v. Selden, 101 U.S. 99, 107 (1879).

21. A paean to that delicate balance fills David Nimmer, Elliot Brown \& Gary N. Frischling, The Metamorphosis of Contract into Expand, 87 CALIF. L. REV. 17 (1999). Many of the themes from that Article carry forward here.

22. See, e.g., Eldred v. Ashcroft, 537 U.S. 186 (2003) (holding extended copyright terms constitutional); Sony Corp. of Am. v. Universal City Studios, Inc., 464 U.S. 417 (1984) (ruling that marking individual copies of complete television shows for the purposes of timeshifting constitutes permissible fair use, not violation of copyright); Harper \& Row, Publishers, Inc. v. Nation Enters., 471 U.S. 539 (1985) (holding that fair use is not an appropriate defense for using excerpts from the unpublished memoirs of President Gerald Ford). Where this line should be drawn has been the subject of extensive academic debate, especially in the last decade. See, e.g., Determann, supra note 1.

23. 17 U.S.C. \ 102(b) (2012). 
most computer programs ${ }^{24}$ lies in their functionality and efficiency. ${ }^{25}$ Enterprise and office software users typically appreciate, and pay for, the speed, reliability, and operational simplicity with which a particular program produces results. The simpler, more common, and more familiar a graphic user interface ("GUI"), the better. ${ }^{26}$ Most software users fail even to notice, and certainly care little or nothing at all for, creative flourishes embedded in the software. ${ }^{27}$

\section{Computer Software Amendment of 1980}

Copyright's dominion over software has long been settled in the United States. Through its amendment of Title 17 of the United States Code (containing the pre-existing Copyright Act) to include the Computer Software Copyright Act of $1980,{ }^{28}$ Congress $^{29}$ chose copyright law as the

24. Video and computer games and other entertainment software are noteworthy exceptions.

25. David G. Luettgen, Functional Usefulness vs. Communicative Usefulness: Thin Copyright Protection for the Nonliteral Elements of Computer Programs, 4 TEX. INTELL. PROP. L.J. 233, 249-60 (1996); see also Determann, supra note 1, at 1438-39.

26. See Lotus Dev. Corp. v. Borland Int'l, Inc., 49 F.3d 807 (1st Cir. 1995), aff'd by an equally divided Court, 516 U.S. 233 (1996) (holding a menu hierarchy not copyrightable and citing concerns with interoperability and unduly burdening customers to learn multiple systems).

27. For a co-author's in-depth discussion of this dissonance, see Determann, supra note 1 , at $1438-42$.

28. Act of Dec. 12, 1980, Pub. L. No. 96-517, \10, 94 Stat. 3028.

29. Congress acted against the backdrop of a special commission, the National Commission on New Technological Uses of Copyrighted Works ("CONTU"), that it had charged with investigating this arena. In his CONTU concurrence, Commissioner and ViceChair Melville Nimmer issued a warning that will be reprised later in this Article:

At the same time I should like to suggest a possible line of demarcation, which would distinguish between protect[a]ble and nonprotect[a]ble software in a manner more consistent with limiting such protection to the conventional copyright arena. This suggestion is made not because I recommend its immediate implementation, but ratherbecause it may prove useful in the years to come if the Commission's recommendation for protection of all software should prove unduly restrictive. In such circumstances it may prove desirable to limit copyright protection for software to those computer programs which produce works which themselves qualify for copyright protection. A program designed for use with a data base, for example, would clearly be copyrightable since the resulting selection and arrangement of items from such data base would itself be copyrightable as a compilation.

CONTU, Final REPORT OF THE NATIONAL COMMission ON NEW TECHNOlOGiCAL Uses OF COPyrighted WOrKs 27 (1979); see David Nimmer, Codifying Copyright Comprehensibly, 51 UCLA L. REV. 1233, 1263-65 (2004). 
vehicle for courts to afford protection to computer programming. ${ }^{30}$ Computer programs (both object and source code versions) therefore now generally find protection under the U.S. Copyright Act. ${ }^{31}$ The underlying code constitutes a literary work. ${ }^{32}$ Output of software, such as screen displays and GUIs, do not constitute software in and of themselves, but can be protected separately from underlying code as literary, pictorial or graphic works. $^{33}$

Copyright law is designed to protect creative expression as an incentive for further creative activity. In line with that goal, the U.S. Supreme Court has unanimously rejected copyright protection for mere "sweat of the brow." "34 A paradox arises in that software's value is usually measured precisely by its functionality and efficiency, ${ }^{35}$ aspects expressly excluded from copyright protection. ${ }^{36}$ In light of that disconnect, judges are faced with the

30. See, e.g., Apple Computer, Inc. v. Franklin Computer Corp., 714 F.2d 1240 (3d Cir. 1983) (finding that a computer program is a literary work and protected under copyright); for an overview, see Mark A. Lemley, Peter S. Menell, Robert P. Merges \& Pamela SAMUELSON, SOFTWARE AND INTERNET LAW 1-45, 97-98 (1st ed. 2000), 33-35 (2d ed. 2003).

31. See, e.g., Williams Elecs., Inc. v. Artic Int'l, Inc., 685 F.2d 870 (3d Cir. 1982); Franklin Computer, 714 F.2d at 1240.

32. Franklin Computer, 714 F.2d at 1246-49.

33. See Stern Elecs., Inc. v. Kaufman, 669 F.2d 852, 855-57 (2d Cir. 1982) (holding that video game manufacturers could copyright image and sounds in a game, not just the underlying source code); Data E. USA, Inc. v. Epyx, Inc., 862 F.2d 204 (9th Cir. 1988); Apple Computer, Inc. v. Microsoft Corp., 35 F.3d 1435 (9th Cir. 1994) (addressing the scope of protection for GUI elements).

34. See Feist Publn's, Inc. v. Rural Tel. Serv. Co., 499 U.S. 340, 352-60 (1991).

35. See Bucklew v. Hawkins, Ash, Baptie \& Co., 329 F.3d 923, 928 (7th Cir. 2003) (finding software whose primary function was improving efficiency copyrightable).

36. Computer Assocs. Int'l, Inc. v. Altai, Inc., 982 F.2d 693, 712 (2d Cir. 1992); see also Mark A. Lemley \& David W. O’Brien, Encouraging Software Reuse, 49 STAN. L. REV. 255 (1997) (arguing that copyright protection for software inhibits efficiency); Peter S. Menell, $A n$ Analysis of the Scope of Copyright Protection for Application Programs, 41 STAN. L. REV. 1045 (1989) (arguing that viewing application programming as literary creativity rather than a technological advancement may give too broad a protection); Samuelson et al., supra note 12 (arguing that law should focus on value and know-how rather than means which might be used to appropriate it). Cf. Jane C. Ginsburg, Four Reasons and a Paradox: The Manifest Superiority of Copyright Over Sui Generis Protection of Computer Software, 94 Colum. L. REV. 2559 (1994) (noting that while imperfect, copyright is preferable to other regimes for protecting software); Arthur R. Miller, Copyright Protection for Computer Programs, Databases, and ComputerGenerated Works: Is Anything New Since CONTU?, 106 HARV. L. REV. 977 (1993) (defending CONTU as a flexible regime to address current and future issues in software copyright); Stacey L. Dogan \& Joseph P. Liu, Copyright Law and Subject Matter Specificity: The Case of Computer Software, 61 N.Y.U. ANN. SuRV. AM. L. 203, 204 (2005) (discussing judicial treatment of computer software copyright protection in light of its dual nature). 
prospect of having to fit a square peg into a round hole. ${ }^{37}$ Courts have developed a number of tests and approaches to separate software's protectable creative elements from its non-protectable functional elements. ${ }^{38}$ Creative elements are protected against literal and non-literal copying. By contrast, functional ingredients can be freely duplicated, particularly when idea and expression (or functionality and creativity) merge or when expression is dictated by external requirements (scènes à faire-for example, a multi-tier technical solution in which certain individual tiers can only be programmed efficiently in one particular manner). ${ }^{39}$ Thus, software copyright analysis must begin with a thorough examination of the dichotomy between creativity and functionality. ${ }^{40}$ This analysis involves filtering out ideas, processes, methods, facts, and elements dictated by external factors or efficiency; material in the public domain; expression which has merged with any of the foregoing; and expression which is so standard or common as to be a "necessary incident" to any of the foregoing. ${ }^{41}$

Software can present questions at multiple levels. Artistic screen displays of computer games (with fantasy figures and landscapes) ${ }^{42}$ bear a greater resemblance to traditional subjects of copyright protection (a novel, a stilllife) than to software in executable form ${ }^{43}$ or to the functionality-driven user

37. See Altai, 982 F.2d at 712 ("Generally, we think that copyright registration-with its indiscriminating availability - is not ideally suited to deal with the highly dynamic technology of computer-science.").

38. Id. at 714; Gates Rubber Co. v. Bando Chem. Indus., Ltd., 9 F.3d 823, 836-38 (10th Cir. 1993); Lotus Dev. Corp. v. Borland Int'l, 49 F.3d 807, 815-17 (1st Cir. 1995), aff'd by an equally divided Court, 516 U.S. 233 (1996); Chamberlain Grp., Inc. v. Skylink Techs., Inc., 381 F.3d 1178, 1191-92 (Fed. Cir. 2004); Lexmark Int'l, Inc. v. Static Control Components, Inc., 387 F.3d 522, 534-36 (6th Cir. 2004); Case C-406/10, SAS Institute Inc. v. World Programming Ltd., 2012 E.C.R. I-0000, at $\$ 46$.

39. See Oracle Am., Inc. v. Google Inc., 872 F. Supp. 2d. 974 (N.D. Cal. 2012), rev'd, 750 F.3d 1339 (Fed. Cir. 2014); Altai, 982 F.2d at 707-08; Case C-406/10, SAS Inst. Inc. v. World Programming Ltd., 2012 E.C.R. I-0000, at 946.

40. See Feist Publn's, Inc. v. Rural Tel. Serv. Co., 499 U.S. 340, 362 (1991); Bateman v. Mnemonics, Inc., 79 F.3d 1532, 1543-45 (11th Cir. 1996); Apple Computer, Inc. v. Microsoft Corp., 35 F.3d 1435, 1443-46 (9th Cir. 1994); Eng'g Dynamics, Inc. v. Structural Software, Inc., 26 F.3d 1335, 1342-47 (5th Cir. 1994); Kepner-Tregoe, Inc. v. Leadership Software, Inc., 12 F.3d 527, 534 (5th Cir. 1994); Gates Rubber, 9 F.3d at 834-37; Atari Games Corp. v. Nintendo of Am., Inc, 975 F.2d 832, 839 (Fed. Cir. 1992); Control Data Sys., Inc. v. Infoware, Inc., 903 F. Supp. 1316, 1322 (D. Minn. 1995); CMAX/Cleveland, Inc. v. UCR, Inc., 804 F. Supp. 337, 352-53 (M.D. Ga. 1992); Brown Bag Software v. Symantec Corp., 960 F.2d 1465, 1475-76 (9th Cir. 1992); MiTek Holdings, Inc. v. Arce Eng'g Co., 89 F.3d 1548, 1554-56 (11th Cir. 1996).

41. Gates Rubber, 9 F.3d at 833, 837-38.

42. See, e.g., Micro Star v. Formgen Inc., 154 F.3d 1107, 1111-12 (9th Cir. 1998).

43. Machine code is not human-readable, consisting of simply "on" or "off" states, typically represented by zeros and ones. 
interfaces found in application programs. ${ }^{44}$ Courts have defined the dividing line on a case-by-case basis in light of the underlying public policy considerations, often disagreeing on methods and results. An example is the epic battle that recently unfolded between Oracle and Google over Google's use of Java application programming interface ("API”) packages. ${ }^{45}$ Whereas the district court had denied copyright protection to the headers, sequence, and organization of the API packages on a number of grounds, ${ }^{46}$ the Federal Circuit Court of Appeals reversed. ${ }^{47}$ Assuming that appellate court determination survives, future defendants will have to prove fair use, merger, or scènes à faire in order to vindicate copying of interfaces, lock-out codes, and other gateways to interoperability. ${ }^{48}$

Some cases have tested copyright law's boundaries with respect to highly valuable aspects of software that were not themselves creative, and hence outside the bounds of copyright protection. ${ }^{49}$ These situations involved companies using otherwise creative works in a purely functional manner, e.g., as interfaces, passwords, or lock-out mechanisms. Courts denied copyright protection for such works, regardless of how creative and original they were, in the interest of preserving the balance between protection and access rights described above. ${ }^{50}$ Thus, when proprietors employ copyrighted works in a

44. See, e.g., Lotus Dev. Corp. v. Borland Int'l, Inc., 49 F.3d 807 (1st Cir. 1995), aff'd by an equally divided Court, 516 U.S. 233 (1996); Computer Assocs. Int'l, Inc. v. Altai, Inc., 982 F.2d 693, 715 (2d Cir. 1992).

45. Oracle, 872 F. Supp. 2d 974, rev'd, 750 F.3d 1339 (Fed. Cir. 2014).

46. 872 F. Supp. 2d at 998.

47. Oracle, 750 F.3d 1339, 1361 (Fed. Cir. 2014).

48. Id. at 1358. The court indicated that it would be difficult for Google to substantiate any of these defenses, based on its determination that Google did not create Android as interoperable with Java, and that Google adopted the API declaring code, organizational sequence, and structures as a mere convenience for developers who were used to the Java environment. $I d$. at 1371 . But, regarding fair use, the court ultimately remanded back to the district court. Id. at 1373-77. In the interim, the Supreme Court expressed interest in reviewing the Federal Circuit's ruling by inviting the Solicitor General to express the views of the United States in the case. 135 S. Ct. 1021 (2015). The latter urged against granting review, in the process rejecting Google's view that the APIs in suit amounted to a "method of operation." Brief for the United States as Amicus Curiae at 14, No. 14-410 (May 26, 2015).

49. See, e.g., Midway Mfg. v. Artic Int'l, Inc., 704 F.2d 1009, 1014 (7th Cir. 1983) ("[T] he amount by which the language of Section 101 must be stretched to accommodate speeded-up video games is, we believe, within the limits within which Congress wanted the new Act to operate.").

50. Oracle Am., Inc. v. Google Inc., 810 F. Supp. 2d 1002 (N.D. Cal. 2011), rev'd, 750 F.3d 1339 (Fed. Cir. 2014) (on technical user interfaces); Sega Enters. Ltd. v. Accolade, Inc., 977 F.2d 1510, 1521 (9th Cir. 1992) (holding that reverse engineering to obtain interface information for compatibility is permissible under narrow circumstances); Chamberlain Grp., Inc. v. Skylink Techs., Inc., 381 F.3d 1178 (Fed. Cir. 2004); Lexmark Int'l, Inc. v. Static Control Components, Inc., 387 F.3d 522 (6th Cir. 2004). 
software context for purposes apart from its creative expression, they cannot uncritically rely on the protections copyright law affords. ${ }^{51}$

\section{International dimension}

Copyright law has established itself globally as the primary intellectual property regime for software. Jurisdictions that initially rejected this approach have since adopted it. ${ }^{52}$ In the thirty-one member states of the European Economic Area ("EEA"), ${ }^{53}$ for example, national copyright law is partially harmonized by Directives of the European Union, in particular the E.U. Software Directive ${ }^{54}$ and the E.U. Copyright Directive. ${ }^{55}$ The E.U. Software Directive grants copyright protection to computer programs as literary works. ${ }^{56}$ Like U.S. copyright law, ${ }^{57}$ the E.U. Software Directive protects only creative elements of computer programs and not functionality, technical interfaces, programming language or data file formats. ${ }^{58}$ As such, the E.U.

51. See Sega, 977 F.2d 1510; Lexmark, 387 F.3d 522. In Oracle America, Inc. v. Google Inc., the Federal Circuit took a narrow view of interoperability and did not accept the adoption of familiar headers or organizational structures for convenience purposes. 750 F.3d 1339, 1361 (Fed. Cir. 2014).

52. An example is Germany: Software had been expressly recognized in Section 2 of the German Copyright Act as a category of copyrightable works since 1985. Urheberrechtsgesetz, UrhG [Copyright Law], Sept. 9, 1965, as amended May 8, 1998 \& 2 no. 2 (F.R.G.) (Ger.). However, prior to the implementation of the EC Software Directive into German law in 1993, German courts had required a very high level of originality before they would afford copyright protection for software. The leading cases are from 1985 and 1991: Bundesgerichtshof [BGH] [Federal Court of Justice] May 19, 1985, 12 Gewerblicher Rechtsschutz und Urheberrecht [GRUR] 1041 (F.R.G.) (known as the collection program case-“'Inkasso-Programm") and Bundesgerichtshof [BGH] [Federal Court of Justice] 1991, 19 Neue Juristische Wochenschrift [NJW] 1231 (F.R.G.) (Ger.) (known as the operating system case-“Betriebssystem"). Many programs that would have easily qualified as copyrightable in the United States were not found to be so in Germany. For an overview of software copyright protection in the European union, see Pamela Samuelson, Comparing U.S. and EC Copyright Protection for Computer Programs: Are They More Different Than They Seem?, 13 J.L. \& COM. 279 (1994).

53. The EEA consists of the 28 EU Member States, which includes Croatia since July 1, 2013, plus Norway, Iceland, and Liechtenstein.

54. Directive 2009/24/EC, of the European Parliament and of the Council of April 23, 2009 on the Legal Protection of Computer Programs, 2009 O.J. (L 111) 16.

55. Directive 2001/29/EC, of the European Parliament and of the Council of 22 May 2001 on the Harmonisation of Certain Aspects of Copyright and Related Rights in the Information Society, 2001 O.J. (L 167) 10.

56. Directive 2009/24/EC, supra note 54, art. 1(1).

57. 17 U.S.C. $\int S 102(a)-(b)(2012)$.

58. Directive 2009/24/EC, supra note 54, art. 1(2); Case C-406/10, SAS Inst. Inc. v. World Programming Ltd., 2012 E.C.R. I-0000, at $₫ 46$. 
Software Directive does not cover GUIs. ${ }^{59}$ Ordinary copyright law can cover a GUI, but only if and to the extent the GUI is sufficiently original and not merely dictated by functional requirements. ${ }^{60}$ Unlike the code that creates the GUI, the GUI itself does not constitute a computer program. ${ }^{61}$

\section{B. Reservation of Privileges to Software Users}

\section{First sale doctrine}

Congress's decision to embrace software within the framework of Title 17 by the Computer Software Copyright Act of 1980 inevitably brought innumerable features of copyright doctrine to the software legal environment. Had Congress chosen a different vehicle, there would have been no importation into the software domain of such incidents of preexisting copyright law as the necessity to place a (C) on computer code; ${ }^{62}$ it would have been unnecessary to register software for protection with the United States Copyright Office; and its infringement need not have been gauged through a standard called "substantial similarity," 33 in turn calibrated by another doctrine called "fair use." 64

Among the many other antecedent doctrines of copyright law imported into the software context by virtue of the 1980 amendment is the "first sale" doctrine. ${ }^{65}$ More than a century ago, in Bobbs-Merrill Co. v. Straus, the U.S. Supreme Court ruled that a book publisher could not use copyright law to enforce minimum resale price covenants against secondary book purchasers, inasmuch as the copyright owner exhausted his right to control distribution after the first sale of each book. ${ }^{66}$ That ruling about the very forgettable novel The Castaway gave birth to a vital feature of copyright law, the first sale doctrine, which was subsequently adopted into legislation and treaties around

59. Case C-393/09, Bezpečnostní softwarová asociace-Svaz softwarové ochrany v. Ministerstvo kultury, 2010 E.C.R. I-13971, at 92.

60. Id. at ๆף 49,51 .

61. Id.

62. Of course, in 1989, incident to joining the Berne Convention, the severity of that requirement was greatly alleviated. See 2 Melville B. Nimmer \& DAVID Nimmer, Nimmer ON COPYRIGHT $\int 7.02$ (2013).

63. See Computer Assocs. Int'l, Inc. v. Altai, Inc., 982 F.2d 693, 715 (2d Cir. 1992). See generally David Nimmer, Richard L. Bernacchi \& Gary N. Frischling, A Structured Approach to Analyzing the Substantial Similarity of Computer Software in Copyright Infringement Cases, 20 ARIZ. ST. L.J. 625 (1988).

64. See 4 Melville B. Nimmer \& David Nimmer, Nimmer on Copyright $\int 13.03[\mathrm{~F}][5]$ (2013); Nimmer, Bernacchi \& Frischling, supra note 63, at 651-56.

65. For a more detailed background on doctrine's origin, see Used Software Sales and Copyright Exhaustion in Europe, 17 BNA ELEC. COM. \& L. REP. 2149 (2012).

66. See Bobbs-Merrill Co. v. Straus, 210 U.S. 339 (1908). 
the world as part of the overall effort to balance exclusion and access rights. Many aspects of the first sale doctrine appear relatively uncontroversial today: for books and many other products, the copyright owner exhausts any exclusive distribution rights regarding a particular a copy at the time that copy is first sold. ${ }^{67}$ Upon that copy's sale, the owner is compensated and cannot use copyright to control its subsequent distribution.

\section{Essential step defense}

With respect to software, however, the first sale doctrine alone cannot protect consumers to the same extent that it operates with respect to books. For novels and cookbooks, the first sale doctrine allows their readers to resell the products through second-hand bookstores, and likewise allows libraries to obtain copies and lend them to patrons. But that doctrine attaches solely to copyright law's distribution right; it has no purchase on the coordinate reproduction right. In other words, the first sale doctrine affords users no ability under the law to copy the subject work. Yet, given that readers have no need to photocopy novels or rewrite recipes, the first sale doctrine affords them all the latitude they need. ${ }^{68}$

But things are very different in the software world. Just to enjoy the very software copy they have acquired, ${ }^{69}$ users need to make reproductions of it. Consider the difference - after John buys a book containing a novel, he can read and reread it a thousand times, no copying necessary; after Jane buys a DVD containing software, by contrast, she cannot use it even once on her PC without copying its contents. Software users typically need to make one permanent copy in the process of installing the software on the computer's hard disk or other persistent storage memory. When consumers use a program, a partial copy of the software is loaded from the persistent memory

67. Nonetheless, we will see below the possibility of unprecedented stress over even that conclusion. See infra Subsection II.B.3.

68. Cf. Stephen McIntyre, Game Over for First Sale, 29 BERKELEY TECH. L.J. 1, 11 (2014) ("The significance of the first sale doctrine can hardly be overstated. This longstanding and fundamental limitation on the public distribution right promotes commerce, safeguards competition, and props up entire industries.") (internal citations and quotations marks omitted).

69. We use the word "acquired" here in a general sense, in order to avoid prejudicing the inquiry to come: Does a user who acquires diskettes containing computer software by paying $\$ 500$ on a one-time basis to the manufacturer thereby "purchase" the physical good in question, or succeed to a different legal relationship with respect to that physical good? Note that the question is not that user's relationship to the copyright in question, which is an intangible. See infra Subsection II.C.1. Instead, the first sale question arises based on the user's relationship to a physical product. Items in point could include diskettes, thumb drives, hard drives, or CD-ROMs. Properly construed, those items would even include a digital download of bits. See 2 Nimmer \& Nimmer, supra note 62, at $\int 8.12$ [E]. 
into the computer's smaller and more agile random access memory (RAM), inasmuch as not all portions of the program code are typically needed for any given usage session. ${ }^{70}$ The computer's central processing unit (CPU) then accesses the partial software copy in RAM and, during the operation, reproduces some smaller amount of the code in the cache memory of the CPU. ${ }^{71}$ The data resides in that cache memory only for extremely short periods, where it can be accessed and executed much faster than in RAM. ${ }^{72}$ During the operation of the CPU, even less data is copied into the CPU registers, comprised of a minuscule amount of memory inside the $\mathrm{CPU}{ }^{73}$ The closer the memory is located to the CPU, where all data are processed via "current" and "no current" signals, the more accessible (faster) and smaller in size it can be, and the shorter the time it needs to be stored. These reproduction activities are dictated entirely by external functionality requirements (storage and execution efficiency), and are unrelated to particular software products or any creative expression embodied in them. Such ephemeral reproductions of small excerpts of code in cache memory and CPU registers do not typically exist long enough to meet the fixation requirement of the U.S. Copyright Act and therefore do not qualify as "copies." 74 Moreover, even if code fragments may remain in cache memory for a few seconds in atypical circumstances, they usually consist of extremely short commands bereft of copyrightability. ${ }^{75}$ By contrast, software portions

70. In general terms, there are differences in the relative amounts of space available in a hard disc, RAM, cache, and registers. For example, Microsoft Office suite has many features that are not required in day-do-day operation. Most Word installations do not need to copy Equations Editor, and not all design templates are needed in Power Point. Thus, for execution (i.e., use), computers create "excerpts" of software, based on purely functional considerations, designed to maximize efficiency.

71. The typical label here is L1 and L2 cache.

72. See Paul Genua, A Cache Primer, Freescale SEmiconductor (2004), http://www.freescale.com/files/32bit/doc/app_note/AN2663.pdf (last visited Oct. 18, 2014); CPU Cache, WIKIPEDIA.ORG, http://en.wikipedia.org/wiki/CPU_cache (last visited Oct. 18, 2014).

73. A register is a small amount of very fast memory in a CPU providing quick access to commonly used values. See, e.g., CPU Register, WIKIPEDIA.ORG, http://en.wikipedia.org/ wiki/CPU_register (last visited Oct. 18, 2014).

74. See Cartoon Network LP, LLLP v. CSC Holdings, Inc., 536 F.3d 121 (2d Cir. 2008). The Act defines "copies" as "material objects, other than phonorecords, in which a work is fixed by any method now known or later developed, and from which the work can be perceived, reproduced, or otherwise communicated, either directly or with the aid of a machine or device." 17 U.S.C. $\int 101$ (2012).

75. See Perfect 10, Inc. v. Amazon.com, Inc., 508 F.3d 1146, 1156 (9th Cir. 2007). Extremely short commands either will not contain enough creative material to meet the originality requirements of the Copyright Act or will fall into carve-outs for functional subject matter under the Act; see also supra Subsection II.A.2. A collection and creative 
reproduced in RAM often contain enough material bearing creative expression and tend to be sufficiently fixed to qualify as a "copy" eligible for protection under U.S. copyright law. Hence, RAM copies tend to implicate the reproduction right belonging to the copyright owner. ${ }^{76}$

The first sale doctrine, being limited to the distribution right, confers no such reproduction right. The upshot, as we have just seen, is that users risk infringement liability simply by running the very software copy they have acquired. Congress redressed this situation through targeted legislation-the same 1980 amendment that conferred protection on software simultaneously added a provision allowing any lawful owner ${ }^{77}$ of a software copy to make such additional copies as are necessary to use the acquired software. ${ }^{78}$ The provision in question is codified as $\mathbb{S} 117$ of the Copyright Act. Like $\ 109$ (the statutory codification of the first sale doctrine), this provision applies to "the owner of a copy of a computer program.",79

\section{Reverse engineering}

From a technical perspective, in order to function in combination, programs have to be interoperable, i.e., capable of exchanging and mutually using information. ${ }^{80}$ Software manufacturers typically try to ensure that their own programs are interoperable with each other. This allows software manufacturers to market seamlessly integrated software suites, thus encouraging a broader consumer adoption of their products. As such, software manufacturers have different agendas regarding programs made by other companies and depending on the market situation. For example,

organization of short phrases as a whole can qualify as copyrightable. See Oracle Am., Inc. v. Google Inc., 750 F.3d 1339, 1362 (Fed. Cir. 2014), but note that short lines of code separately copied briefly in cache to execute the code may not qualify.

76. See Stenograph L.L.C. v. Bossard Assocs., Inc., 144 F.3d 96, 101-02 (D.C. Cir. 1998); MAI Sys. Corp. v. Peak Computer, Inc., 991 F.2d 511, 518 (9th Cir. 1993). See generally Vincent J. Roccia, What's Fair is (Not Always) Fair on the Internet, 29 RuTGERS L. J. 155 (1997).

77. As will be seen by the wording of the statute quoted in the next footnote, the copy that has been acquired, in order to fall under the first sale doctrine, must be owned by the user. Thus arises the Vernor v. Autodesk, Inc. construction to be explicated at length below. 621 F.3d 1102 (9th Cir. 2010).

78. " [] $\mathrm{t}$ is not an infringement for the owner of a copy of a computer program to make or authorize the making of another copy or adaptation of that computer program provided: (1) that such a new copy or adaptation is created as an essential step in the utilization of the computer program in conjunction with a machine and that it is used in no other manner." 17 U.S.C. $\int 117(\mathrm{a})(1)$ (2012).

79. Id. $\int 117(\mathrm{a})$. The language of the other provision actually refers more generally to "the owner of a particular copy" of a program. Id. 109(a) (2012).

80. See, e.g., Interoperability, WIKIPEDIA.ORG, http://en.wikipedia.org/wiki/ Interoperability\#Software (last visited Dec. 29, 2014). 
companies with an established platform may wish, at times, to prevent interoperability with third-party software in order to protect their market share for add-on programs ${ }^{81}$ or to foster hardware sales. ${ }^{82}$ But new market entrants may try to achieve or promote interoperability with third-party software in order to establish their platforms or to be able to offer add-ons or substitute programs for already established and widely adopted platforms. $^{83}$

In the interest of optimizing the balance between exclusion and access rights, and to further innovation, courts have invoked copyright law's fair use doctrine $^{84}$ to allow intermediate copying of software code for purposes of reverse engineering and creating interoperable ${ }^{85}$ (and even substituting ${ }^{86}$ ) software products. Courts have also allowed the circumvention of technological protection measures to achieve interoperability of softwarehardware combinations. ${ }^{87}$ Those constructions underwrite copyright law's purpose of promoting creativity and innovation in the software field.

\section{DIVERGENT INTERPRETATIONS OF SOFTWARE COPYRIGHT IN AND BETWEEN THE UNITED STATES AND THE EUROPEAN UNION}

\section{Starting in the United States}

Given that software constitutes a form of "literary work" in the eyes of the Copyright Act, ${ }^{88}$ and that traditional exemplars of that genre-paperback novels, fine cookbooks, and multi-volume textbooks - can be freely vended by second-hand bookstores and lent out to library patrons, it follows that software is subject to the same exploitations. The danger thereby arises that one customer buys an expensive software suite and rents it to successive

81. See Sega Enters. Ltd. v. Accolade, Inc., 977 F.2d 1510 (9th Cir. 1992).

82. Sony Computer Entm't, Inc. v. Connectix Corp., 203 F.3d 596 (9th Cir. 2000), cert. denied, 531 U.S. 871 (2000); Lexmark Int'l, Inc. v. Static Control Components, Inc., 387 F.3d 522 (6th Cir. 2004); Chamberlain Grp., Inc. v. Skylink Techs., Inc., 381 F.3d 1178 (Fed. Cir. 2004).

83. Cerulean Studios, for instance, offers a software program entitled "Trillian." Trillian is essentially a third-party user interface for various instant-messaging programs. It claims to support AOL's Instant Messenger (“AIM”), ICQ, Microsoft's MSN Messenger, Yahoo!'s Messenger, and traditional Internet Relay Chat ("IRC"). It acts as both an add-on and a full substitute for all the major instant-messaging programs. It does so without requiring the end-user to install the various instant-messaging software programs that it interfaces with. See CERULEAN STUDIOS, http://www.ceruleanstudios.com/ (last visited May 31, 2013).

84. See 17 U.S.C. $\int 107$ (2012).

85. See Sega, 977 F.2d at 1510.

86. Connectix, 203 F.3d at 596.

87. Skylink, 381 F.3d at 1178; Lexmark, 387 F.3d at 522.

88. See 17 U.S.C. $\int 101$ (2012). 
"library customers" for them to make their own copies. Congress took explicit note of that danger. In 1990, it amended the first sale doctrine to forbid rental of software. ${ }^{89}$ At present, libraries are therefore forbidden from lending software, except under specified circumstances (such as those that operate at university libraries)..$^{90}$

Of course, the amendment leaves software users perfectly free to sell the copies of software in their possession, ${ }^{91}$ even if they cannot rent it. Software companies have tried to avoid the implications of that state of affairs by labeling their transactions with customers as "licenses" rather than as "sales" of the physical medium. ${ }^{92}$ These companies have drafted shrinkwrap agreements to the effect that software copies are only licensed, never sold, and that they never transfer ownership to those physical products embodying their software. Without an authorized first sale, software copies cannot even be used on a computer without additional permission from the copyright owner. ${ }^{93}$ Thus, someone in possession of a copy of software cannot use it for its intended purpose, except insofar as those rights are explicitly granted in the subject "license." 94

At this point, we enter highly contested terrain. Dissension extends to courts, scholars, and countries. Without purporting to cover the field, some highlights deserve brief mention. ${ }^{95}$ One point of view, adopted by some

89. The amendment in question is the Computer Software Rental Amendments Act of 1990, Pub. L. No. 101-650, \801, 104 Stat. 5089. It is codified as a part of the first sale doctrine, as it limits the user privileges that would otherwise be as available to owners of copies of software as is available to owners of copies of novels and cookbooks, namely to rent them out.

90. See 17 U.S.C. \109(b)(1)(A) (2012). For an analysis, see 2 NimMER \& NimmER, supra note 62 , at $\int 8.12[\mathrm{~B}][8]$.

91. Below, this Article will draw further distinctions between possession and ownership.

92. The question pointedly is not whether a license or sale of the intangible copyright has been acquired. Plainly, someone who pays $\$ 25$ for the paper and cardboard comprising a novel is only a licensee of the copyright, the same as someone who pays $\$ 500$ for set of CDROMs comprising a software suite is similarly only a licensee of that copyright. See supra note 69.

93. See supra Part II.B.2.

94. See supra Part II.B.3.

95. See Jean Braucher, Contracting Out of Article 2 Using a "License" Label: A Strategy that Should Not Work for Software Products, 40 LOY. L.A. L. REV. 261 (2006); Brian W. Carver, Why License Agreements Do Not Control Copy Ownership: First Sales and Essential Copies, 25 BERKELEY TECH. L.J. 1887 (2010); Andrew Chin, Antitrust Analysis in Software Product Markets: A First Principles Approach, 18 HARV. J.L. \& TECH. 1 (2004); William W. Fisher III, When Should We Permit Differential Pricing of Information?, 55 UCLA L. REV. 1 (2007); Nancy S. Kim, The Software Licensing Dilemma, 2008 BYU L. REV. 1103 (2008); Michael J. Madison, Reconstructing the Software License, 35 LOY. U. CHI. L.J. 275 (2003); Gregory E. Maggs, The Waning Importance of 
courts and scholars (including one of the current co-authors, who was born on U.S. shores), focuses on the particular medium embodying the software. ${ }^{96}$ If that medium falls within the dominion of the user, then it is a sale. ${ }^{97}$ Thus, just as someone who has paid $\$ 15$ for the hard- or paperback version of The Castaway can freely write in its margins, tear out chapter three, burn the whole, re-purpose it as a paperweight, or shellac it to use as a doorstop, the same considerations apply to someone who has paid $\$ 490$ for a set of CD-ROMs that embody AutoCAD software. That individual is likewise free to punch a hole in disc two, re-purpose disc one as a Frisbee, burn all three discs, or shellac the set to use as a doorstop. In Vernor v. Autodesk, Inc., at the trial court level, Judge Richard Jones adopted this first viewpoint concerning AutoCAD software. ${ }^{98}$

The contrary point of view, adopted by some courts and scholars (including the other co-author of this Article, whose birth traces back to the Continent), defers more or less to the characterization of the transaction concerning a software copy in the first agreement with the copyright owner. If the copyright owner does not agree to a sale of a software copy, then neither the first acquirer nor any downstream buyers can become an "owner" who thereby acquires rights under \$S 109 or 117 of the Copyright Act. Among followers of this viewpoint, opinions vary as to just how much deference is due the wishes of the copyright owner. Some maintain the copyright owner should be able to preclude a sale simply by stating in a form agreement that a license is intended. ${ }^{99}$ Others believe a more substantive

Revisions to U.C.C. Article 2, 78 Notre Dame L. ReV. 595 (2003); David A. Rice, Copyright and Contract: Preemption After Bowers v. Baystate, 9 RogeR Williams U. L. REV. 595 (2004); John A. Rothchild, The Incredible Shrinking First-Sale Rule: Are Software Resale Limits Lawful?, 57 RutGers L. REV. 1 (2004).

96. For a long treatment of the cases in question, with one of the current co-author's evaluation, see 2 NimMER \& NimMER, supra note 62, at \8.12[B][d][i][III].

97. Emblematic here is the following:

The Court finds that the circumstances surrounding the transaction strongly suggests that the transaction is in fact a sale rather than a license. For example, the purchaser commonly obtains a single copy of the software, with documentation, for a single price, which the purchaser pays at the time of the transaction, and which constitutes the entire payment for the "license." The license runs for an indefinite term without provisions for renewal. In light of these indicia, many courts and commentators conclude that a "shrinkwrap license" transaction is a sale of goods rather than a license.

Softman Prods. Co., LLC v. Adobe Sys. Inc., 171 F. Supp. 2d 1075, 1085 (C.D. Cal. 2001).

98. 555 F. Supp. 2d 1164 (W.D. Wash. 2008).

99. In MAI Systems Corp. v. Peak Computer, Inc., the court commented in a footnote: "Since MAI licensed its software, the Peak customers do not qualify as 'owners' of the 
analysis is warranted to determine how "sales-like" the commercial terms of the transaction really are, regardless of the title of the agreement. ${ }^{100}$ But, despite such distinctions, all varieties of this viewpoint allow the software industry to opt out of the first sale doctrine.

Defenders of this latter position focus on the economics and valuepropositions of the software industry. ${ }^{101}$ To a large enterprise, a computer program can add immense value that is well worth the hundreds of thousands of dollars paid for a license. By contrast, a student, an educational institution, or a small business derives a much smaller economic benefit, and, concomitantly, can afford to pay much less. If the software copyright owner had to charge each user the same price to recoup development costs, the optimal price point will be somewhere in the middle. Here, the copyright owner misses out on the difference between the price charged and the price that large enterprises would be willing to pay, while also sacrificing the sales it would have made to students at a lower price. However, if copyright owners charge different prices and do not control distribution, they create an opportunity for arbitrage. For example, if a copyright owner charges students $\$ 5$ and large enterprises $\$ 9$, a student may purchase a copy and immediately sell that copy to a large company for up to $\$ 9$, pocketing the margin. And the copyright owner then misses out on differences between the educational price and large-enterprise price. Or, a large enterprise could purchase multiple licenses at favorable volume prices and sell some copies to other businesses. Here, the copyright owner misses out on an opportunity to sell single copies without discount. Given the relatively high potential for value differential with respect to computer programs and user bases, software companies have been particularly keen on controlling distribution and avoiding arbitrage.

Reverting to Vernor v. Autodesk, Judge Callahan on appeal vacated the judgment below. ${ }^{102}$ The Court of Appeals for the Ninth Circuit decided to

software and are not eligible for protection under $\int 117 . " 991$ F.2d 511, 518 n.5 (9th Cir. 1993).

100. Lothar Determann \& Aaron Xavier Fellmeth, Don't Judge a Sale by Its License: Software Transfers Under the First Sale Doctrine in the United States and the European Community, 36 U.S.F. L. REv. 1, 105 (2001); see also DSC Commc'ns Corp. v. Pulse Commc'ns, Inc., 170 F.3d 1354, 1360-62 (Fed. Cir. 1999).

101. See, e.g., Christian H. Nadan, Software Licensing in the 21st Century: Are Software "Licenses" Really Sales, and How Will the Software Industry Respond?, 32 AIPLA Q. J. 555 (2004).

102. 621 F.3d 1102 (9th Cir. 2010). Technically, this appeal relates to Judge Jones's later opinion in this case, rather than the published opinion cited above. It is to be added that unadorned invocations of Vernor in the balance of this article refer to the Ninth Circuit ruling rather than to the various district court rulings in that case. 
defer to the copyright owner and its license terms. ${ }^{103}$ The effect, as the same appellate court expressly conceded four years earlier, is that "the first sale doctrine rarely applies in the software world because software is rarely 'sold.'"104 At this point, the prevailing view in the United States inclines towards this latter viewpoint. ${ }^{105}$

Insofar as this ruling is rooted in the first sale doctrine, it applies across the board to all copyrighted works (rather than setting up a special rule for software). ${ }^{106}$ Conversely, insofar as it is rooted in the essential step defense, then the matter applies solely to software. ${ }^{107}$ Nonetheless, in a software copyright case (such as Vernor), the identical licensing terms that defeat the first sale doctrine likewise doom the essential step defense. ${ }^{108}$

\section{Moving to Europe}

As we shift our focus eastward, it is necessary to note at the outset that the European legislative framework provides for more rigid versions of fair use and essential step doctrines relating to software. Under the E.U. Software Directive, a software user needs authorization from the copyright owner with respect to "the permanent or temporary reproduction of a computer program by any means and in any form, in part or in whole" including by way of "loading, displaying, running, transmission or storage of the computer program." ${ }^{\text {109 }}$ But, any

person having a right to use a copy of a computer program shall be entitled, without the authorisation of the rightholder, to observe,

103. 'Since the plaintiff's license imposed 'significant restrictions' on the defendant's software rights, the defendant was a licensee and was not entitled to the essential step defense." Id. at 1110.

104. Wall Data Inc. v. L.A. Cnty. Sheriff's Dep't, 447 F.3d 769, 785 n.9 (9th Cir. 2006).

105. See Softman Prods. Co., LLC v. Adobe Sys. Inc., 171 F. Supp. 2d 1075, 1085 (C.D. Cal. 2001); DSC Commc'ns Corp., 170 F.3d at 1360; Data Prods., Inc. v. Reppart, 18 U.S.P.Q.2d 1058, 1601 (D. Kan. 1990); ISC-Bunker Ramo Corp. v. Altech, Inc., 765 F. Supp. 1310, 1314 (N.D. Ill. 1990); Davidson \& Assocs., Inc. v. Internet Gateway, 334 F. Supp. 2d 1164, 1177 (E.D. Mo. 2004); Microsoft Corp. v. Harmony Computers \& Elecs., Inc., 846 F. Supp. 208, 213 (E.D.N.Y. 1994); Novell, Inc. v. Network Trade Ctr., Inc., 25 F. Supp. 2d 1218, 1230 (D. Utah 1997).

106. To derive the proper construction of the first sale doctrine, the court looked to past precedent ranging across all subject matters, from film prints to software itself.

107. Vernor, 621 F.3d at 1107. As noted above, Congress added the essential step defense of $\int 117$ in the context of the 1980 computer amendments, applicable solely to software.

108. Id. (The reason is that those doctrines work in tandem. As the Ninth Circuit itself commented in this case, "both of these affirmative defenses are unavailable to those who are only licensed to use their copies of copyrighted works").

109. Directive 2009/24/EC, supra note 54, art. 4(1)(a). 
study or test the functioning of the program in order to determine the ideas and principles which underlie any element of the program if he does so while performing any of the acts of loading, displaying, running, transmitting or storing the program which he is entitled to do. ${ }^{110}$

This statutory right cannot be restricted by contract. ${ }^{111}$ In addition to this statutory right to copy for purposes of reverse engineering, Article 5(1) of the E.U. Software Directive provides a defense similar to $\int 117(\mathrm{a})$ of the U.S. Copyright Act. If and to the extent reproduction is "necessary for the use of the computer program by the lawful acquirer in accordance with its intended purpose, including for error correction," the software user does not need authorization from the copyright owner, except as otherwise agreed via contract. $^{112}$ Thus, if the copyright owner does not address the topic in a software license agreement, or if a secondary user is not in privity of contract, the lawful user is free to reproduce the software copy as necessary for the use of the program in accordance with its intended purpose. These statutory rights extend to lawful users and acquirers respectively, not only to owners of a copy as under the comparable feature of the U.S. Copyright Act.

The right to "communicate to the public" copyrighted works under the E.U. Copyright Directive (for example, by streaming or arranging for the download of music files over the internet) is not exhausted by a first communication. ${ }^{113}$ But a first sale of a software or music file exhausts distribution rights under the E.U. Software Directive and E.U. Copyright Directive, respectively. The first sale doctrine, as applied to software copyrights, is framed in the same way as its counterpart in the U.S. Copyright Act: "The first sale in the Community of a copy of a program by the rightholder or with his consent shall exhaust the distribution right within the Community of that copy, with the exception of the right to control further rental of the program or a copy thereof." Notably, a sale is required and mere acquirers or lawful users of software copies are not expressly protected (unlike with respect to reverse engineering and reproduction as an essential step of using software).

110. Directive 2009/24/EC, supra note 54, art. 5(3).

111. Directive $2009 / 24$ /EC, supra note 54 , art. 8 .

112. Directive 2009/24/EC, supra note 54, arts. 5(1), (3). Contractual clauses that seek to restrict use of the software program for purposes of decompilation are invalid, see Directive 2009/24/EC, supra note 54, art. 8; Case C-406/10, SAS Inst. Inc. v. World Programming Ltd., 2012 E.C.R. I-0000, at $\uparrow \uparrow ~ 57,58$.

113. Directive 2001/29/EC, supra note 55, art. 3(3). 
Yet, in Europe, courts have taken a different viewpoint on what kinds of transactions qualify as sales. ${ }^{114}$ In general, European courts give much less weight to contract terms, particularly in standard contracts imposed by software companies in the form of shrinkwrap or click-through license agreements. ${ }^{115}$ Moreover, E.U. law is strongly opposed to allowing companies to segment the "Common Market" in the EEA. As the E.U.'s "engine of integration," 116 the European Court of Justice propels the effort to strengthen European economic unification. Since copyrights are territorial and, in the thirty-one EEA states, convey national rights, copyright laws tend to obstruct-or allow companies to obstruct-rather than galvanize, borderless trade in Europe. Accordingly, the E.U. Court of Justice has, to intellectual property's detriment, a predilection for recognizing copyright defenses and exceptions. ${ }^{117}$

Rooted in policy principles, on July 3, 2012, the E.U. Court of Justice held in Oracle $v$. Usedsoft that a software copyright owner may not prevent the resale of software copies that are downloaded with the copyright owner's consent over the internet, notwithstanding the initial acquirer's earlier agreement with the software copyright owner that the software copies are licensed only to the initial acquirer and shall not be resold. ${ }^{118}$ The E.U. Court embraces the view-one previously taken by German courts ${ }^{119}$ — that any transfer of possession without a time limit for a lump sum fee constitutes a sale and triggers the first sale doctrine. ${ }^{120}$

The E.U. Court also expands this view to apply to software downloads and indicates that someone who acquires a software copy lawfully, i.e., from the copyright owner, with the copyright owner's consent or from a secondary

114. See Determann \& Fellmeth, supra note 100; see also Lothar Determann, Importing Software and Copyright Law, 30 COMPUTER \& INTERNET LAW. 1, 4 (2013).

115. See Lothar Determann, Notice, Assent Rules for Contract Changes After Douglas v. U.S. District Court, 12 BNA ElECT. COM. \& L. REP. 1 (2007); James R. Maxeiner, Standard-Terms Contracting in the Global Electronic Age: European Alternatives, 28 YALE J. INT'L L. 109 (2003); see also Jessica Gallegos, A New Role for Tortious Interference in the Digital Age: A Model to Enforce End User License Agreements, 38 FLA. ST. U. L. REV. 411 (2011); Mark A. Lemley, Intellectual Property and Shrinkwrap Licenses, 68 S. CALIF. L. REV. 1239, 1246, 1261, 1267-84 (1995); Margaret Jane Radin, Reconsidering Boilerplate: Confronting Normative and Democratic Degradation, 40 CAP. U. L. REV. 617 (2012).

116. See, e.g., Matthew Gabel, The European Court of Justice as an Engine of Economic Integration: Reconsidering Evidence that the ECJ has Expanded Economic Exchange in Europe (Aug. 5, 2009), available at http:// papers.ssrn.com/sol3/papers.cfm?abstract_id=1444500.

117. Importing Software and Copyright Law, supra note 114, at 4-5.

118. Case C-128/11, UsedSoft GmbH v. Oracle Int'l Corp., 2012 E.C.R. I-0000, 2012 O.J. (C 287) 16, at $\uparrow \uparrow 44-46$; see Determann \& Batchelor, supra note 65.

119. See Determann \& Fellmeth, supra note 100, at 92-101.

120. See Importing Software and Copyright Law, supra note 114, at 5. 
distributor after exhaustion kicks in, may make and sell an additional copy so long as the original software copy is made "unusable," recently been rejected in the United States with respect to digital music files. ${ }^{122}$ Consequently, downloaded software copies can be resold much more easily in Europe, because they can be freely separated from media or devices where they are originally installed.

Going even further, and on unclear legal grounds, the E.U. Court indicates that, after copyright exhaustion kicks in, secondary purchasers may transfer licenses relating to software copies that are transferred in sales-like transactions. ${ }^{123}$ While the first sale doctrine does not itself address the transfer of license agreements, it seems that the E.U. Court of Justice expands the scope of the first sale doctrine from copyright to contracts law based on mere policy considerations, to give the doctrine force. Finally, the E.U. Court of Justice ruled that any contractual agreements to the contrary would not be enforceable, regardless of party sophistication or equal bargaining strength.

In short order, German courts blessed the resale of software copies that were first licensed to educational institutions (subject to heavy discounts and restrictive licenses) and subsequently sold to UsedSoft for the purposes of further resale and margin arbitrage. ${ }^{124}$

Emblematic of the turmoil in this field is that U.S. courts have moved in one direction, and European courts in the opposite. Scholars remain divided; one need only add that the American co-author of this Article sides with the governing view in Europe, whereas the European co-author sides with the precedential view articulated in the United States.

\section{Cross-breezes: exceptions in United States and E.U. to the paradigms set forth above}

Life is never static; the winds that have blown easterly may switch west on a moment's notice. The cases discussed above, in like measure, established rules that have been buffeted and subverted by more recent cases

121. Case C-128/11, UsedSoft GmbH v. Oracle Int'l Corp., 2012 E.C.R. I-0000, 2012 O.J. (C 287) 16, at 970.

122. See Capitol Records, LLC v. ReDigi Inc., 934 F. Supp. 2d 640, 650 (S.D.N.Y. 2013) (stating that, for the purposes of violating the reproduction right, it is irrelevant whether the original phonorecord no longer exists after making a copy).

123. Case C-128/11, UsedSoft GmbH v. Oracle Int'l Corp., 2012 E.C.R. I-0000, 2012 O.J. (C 287) 16, at 9甲 67, 84-85.

124. See, e.g., OLG Frankfurt am Main (German Court of Appeals), Nov. 6, 2012, Az. 11-U68-11 (Adobe v. Usedsoft). 
in both the New World and the Old. A brief foray into subsequent jurisprudence is therefore indicated.

a) Returning Stateside

The latest hurricane from the United States arose in its construction of the first sale doctrine of U.S. copyright law in the context of literary works (albeit in the form of textbooks, rather than computer software). Until recently, it was widely assumed that a sale abroad of copies made outside the U.S. would not exhaust distribution rights under U.S. copyright law, because copyrights are territorial. ${ }^{125}$ In Europe, for example, the E.U. Court of Justice has held that sales in the United States or elsewhere outside the EEA do not exhaust intellectual property rights within the EEA. ${ }^{126}$ So the mirror result was contemplated under U.S. law, in accordance with the very first opinion to address that thorny issue. ${ }^{127}$

But reality diverged from expectations. In Kirtsaeng v. John H. Wiley \& Sons, ${ }^{128}$ the U.S. Supreme Court ruled that copies lawfully made and first sold abroad could be imported into the United States and resold without the U.S. copyright owner's consent. Supap Kirtsaeng had imported books from Thailand and asserted the first sale doctrine as a defense when a U.S. copyright owner, John Wiley \& Sons, Inc., sued him for copyright infringement. ${ }^{129}$ The Second Circuit had rejected the defense based on territoriality considerations, holding the first sale defense inapplicable insofar as the copies were not made in the United States, meaning that no authorized first sale had occurred in the United States. ${ }^{130}$ But in a majority opinion written by Justice Breyer, the Supreme Court reversed, holding that a first sale outside the U.S. qualifies for the defense. ${ }^{131}$

125. "Section 109(a), properly read, affords Kirtsaeng no defense against Wiley's claim of copyright infringement. The Copyright Act, it has been observed time and again, does not apply extraterritorially.” Kirtsaeng v. John Wiley \& Sons, Inc., 133 S. Ct. 1351, 1376 (2013) (Ginsburg, J., dissenting).

126. Case C-479/04, Laserdisken ApS v. Kulturministeriet, 2006 E.C.R. I-8089, 30, ๆ 24; see also Case C-355/96, Silhouette Int'l Schmied GmbH \& Co. KG v. Hartlauer Handelsgesellschaft mbH, 1998 E.C.R. I-4799 (regarding exhaustion under trademark law).

127. Columbia Broad. Sys., Inc. v. Scorpio Music Distribs., Inc., 569 F. Supp. 47 (E.D. Pa. 1983), aff'd mem., 738 F.2d 424 (3d Cir. 1984). Notwithstanding that 1983 opinion, the Third Circuit later came to basically the opposite conclusion. See Sebastian Int'l, Inc. v. Consumer Contacts (PTY) Ltd., 847 F.2d 1093, 1099 (3d Cir. 1988).

128. Kirtsaeng, 133 S. Ct. 1351.

129. Id. at $1357-58$.

130. John Wiley \& Sons, Inc. v. Kirtsaeng, 654 F.3d 210 (2d Cir. 2011), rev'd, 133 S. Ct. 1351 (2013).

131. Kirtsaeng, 133 S. Ct. at 1371. Previously, the Court had ruled that U.S.-made copies that had been sold abroad with the U.S. copyright owner's authorization could be imported 
Although Kirtsaeng dealt with books, the Supreme Court examined a variety of factors favoring international exhaustion of the copyright owner's exclusive right of distribution, including the implications for software. ${ }^{132}$ Neither the parties nor the justices questioned whether Kirtsaeng owned the copies that he sold in the United States. Book publishers have not historically tried to draw a distinction between ownership to the physical book and a "license" of that physical item. Unlike software companies, book publishers have been content to "sell" copies of their works and have not required distributors and end users to accept "license agreements" that purportedly allow only certain uses and concomitantly forbid transfers. ${ }^{133}$

The Kirtsaeng majority found comfort in the fact that its interpretation of the first sale doctrine in current U.S. copyright law is aligned with the common law version of the first sale doctrine relating to the transfer of ownership to chattels that comes with an "impeccable historic pedigree."134 Citing seventeenth century opinions relating to property, the Supreme Court notes, "[t]he 'first sale' doctrine also frees courts from the administrative burden of trying to enforce restrictions upon difficult-to-trace, readily movable goods." 135

Of course, that sensibility is exactly contrary to the Ninth Circuit's ruling in Vernor v. Autodesk, which is entirely premised on enforcing restrictions upon readily movable goods. Moreover, Kirtsaeng also challenges the twin rationales on which Vernor has been defended-its blanket obeisance to terms embodied by copyright owners onto copies of their works, and its facilitation of price discrimination.

The Kirtsaeng majority viewed its ruling as vindication of the Court's own earlier ruling in Bobbs-Merrill Co. v. Straus, stating that "copyright laws were not intended to create a right which would permit the holder of the

against the U.S. copyright owner's will. See Quality King Distribs., Inc. v. L'Anza Research Int'l, Inc., 523 U.S. 135 (1998).

132. "'A]utomobiles, microwaves, calculators, mobile phones, tablets, and personal computers' contain copyrightable software programs or packaging. . . . Many of these items are made abroad .... A geographical interpretation would prevent the resale of, say, a car, without the permission of the holder of each copyright on each piece of copyrighted automobile software." Kirtsaeng, 133 S. Ct. at 1365.

133. Nonetheless, they have relied on geographical exclusivity on those sold copies. See, for example, the notice that the copyright owner in Kirtsaeng included in its books: "Copyright 2008 John Wiley \& Sons (Asia) Pte Ltd. All rights reserved. This book is authorized for sale in Europe, Asia, Africa, and the Middle East only and may be not exported out of these territories." J. WALKER, FUnDAMENTALS OF PHYSICS vi (Wiley Int'l Student ed., 8th ed. 2008).

134. Kirtsaeng, 133 S. Ct. at 1353.

135. Id. at 1363. 
copyright to fasten, by notice in a book ... a restriction upon the subsequent alienation of the subject-matter of copyright after the owner had parted with the title to one who had acquired full dominion over it." "136 In that 1908 case, the copyright owner had purported to impose its own license terms: "The price of this book at retail is one dollar net. No dealer is licensed to sell it at a less price, and a sale at a less price will be treated as an infringement of the copyright." 137 Of course, the Court's refusal to bow to those "license" terms is precisely what gave birth to the first sale doctrine that, over a century later, Kirtsaeng continued to vindicate.

Moving to price discrimination, ${ }^{138}$ the Court's previous foray into this domain had unanimously, in a single sentence, rejected that feature as a basis for its decision. ${ }^{139}$ This time, although the dissent would have upheld price discrimination, ${ }^{140}$ the six justices in the majority, conceding that their interpretation might make price discrimination impossible, nonetheless explicitly disclaimed that consideration as legally cognizable for purposes of copyright doctrine. ${ }^{141}$

136. Id. at 1367 (quoting Bobbs-Merrill Co. v. Straus, 210 U.S. 339, 349-50 (1908)) Most of that same quotation, in turn, was earlier articulated by the unanimous Court in its earlier opinion. See Quality King Distribs., Inc. v. L'Anza Research Int'l, Inc., 523 U.S. 135, 141 (1998).

137. Bobbs-Merrill, 210 U.S. at 341.

138. Reverting to Vernor $v$. Autodesk, Inc., the plaintiff copyright owner urged that same argument. 621 F.3d 1102, 1114-15 (9th Cir. 2010). "Autodesk contends that this (1) allows for tiered pricing for different software markets, such as reduced pricing for students or educational institutions; (2) increases software companies' sales; (3) lowers prices for all consumers by spreading costs among a large number of purchasers; and (4) reduces the incidence of piracy by allowing copyright owners to bring infringement actions against unauthorized resellers." The Ninth Circuit allowed that there are "serious contentions on both sides" of the policy argument. Id. at 1115.

139. Quality King Distribs., 523 U.S. at 153 ("[W]hether or not we think it would be wise policy to provide statutory protection for such price discrimination is not a matter that is relevant to our duty to interpret the text of the Copyright Act.").

140. "Because economic conditions and demand for particular goods vary across the globe, copyright owners have a financial incentive to charge different prices for copies of their works in different geographic regions. Their ability to engage in such price discrimination, however, is undermined if arbitrageurs are permitted to import copies from low-price regions and sell them in high-price regions. The question in this case is whether the unauthorized importation of foreign-made copies constitutes copyright infringement under U.S. law." Kirtsaeng, 133 S. Ct. at 1374 (Ginsburg, J., dissenting).

141. An excerpt reads as follows:

Wiley and the dissent claim that a nongeographical interpretation will make it difficult, perhaps impossible, for publishers (and other copyright holders) to divide foreign and domestic markets. We concede that is so. A publisher may find it more difficult to charge different prices for the same book in different geographic markets. But we do not see how these facts 
The stark contrast between Vernor and Kirtsaeng comes into high relief when one reflects that a full-throttled application of the former could have obviated any need for the latter even to arise. Taken at face value, the Ninth Circuit's pronouncement that its ruling applies across the board to all copyrightable works ${ }^{142}$ opens the door for the publishing industry to adopt the same expedients used by software manufacturers. At the dawn of software commercialization, purveyors had sold products for a fixed sum, with the tangible medium remaining perpetually with the purchaser. ${ }^{143}$ At a later point in time, the same companies began to unilaterally style the transaction as a "license" of products for a fixed sum, with the tangible medium remaining perpetually with the "licensee"—but subject to a "license term" against its further distribution. The Ninth Circuit's vindication of that stratagem as a general matter of copyright law thus furnishes a clear roadmap to John Wiley \& Sons and its fellow purveyors of textbooks: whereas they used to sell a given volume for $\$ 45$, now they need only wrap it in cellophane (covering a printed form limiting user rights) and pronounce the resulting transaction at the same $\$ 45$ price point a "license." In that manner, Wiley et al. not only would be able to forestall importation of the subject books, but also would likewise be able to prevent the books from being sold at second-hand bookstores, or even lent from libraries. In this way, the Ninth Circuit's previous recognition that "the first sale doctrine rarely applies"144 would be generalized from "the software world" to the entire panoply of copyrightable expression.

To be sure, it is easy to imagine that a future Ninth Circuit panel would reaffirm application of Vernor to the world of books, even after Kirtsaeng. Its

help Wiley, for we can find no basic principle of copyright law that suggests that publishers are especially entitled to such rights.

... . [T]he Constitution's language nowhere suggests that its limited exclusive right should include a right to divide markets or a concomitant right to charge different purchasers different prices for the same book, say to increase or to maximize gain. Neither, to our knowledge, did any Founder make any such suggestion. We have found no precedent suggesting a legal preference for interpretations of copyright statutes that would provide for market divisions.

To the contrary, Congress enacted a copyright law that (through the "first sale" doctrine) limits copyright holders' ability to divide domestic markets. And that limitation is consistent with antitrust laws that ordinarily forbid market divisions.

Id. at $1370-71$ (citations omitted).

142. See supra Subsection II.C.3.a)

143. See generally Leonard J. Kennedy \& Lori A. Zallaps, If it Ain't Broke ... The FCC and Internet Regulation, 7 COMMLAW CONSPECTUS 17 (1999).

144. See supra text accompanying note 104. 
logic would be: We are bound to give expansive reach to the first sale doctrine by governing Supreme Court authority; but plaintiffs Random House and Harcourt Brace at bar are no longer engaging in "sale" of their works, so that doctrine has no purchase anymore; instead, the subject books should be viewed as "licensed" only. Yet it seems equally possible that a future Supreme Court, confronted with the issue, would reject that extension of Vernor's construction. We return to those considerations presently. ${ }^{145}$

b) Final European Jaunt

By the same token, finality is evanescent across the Atlantic as well. In particular, brief mention should be made of two recent decisions at the trial court level, one limiting Oracle's ruling to software ${ }^{146}$ and the other potentially expanding the effect of the decision exponentially.

On March 5, 2013, a German consumer protection watchdog lost a lawsuit against the operator of a website that was selling non-transferable licenses to electronic books and music files. The watchdog had complained that the contractual resale prohibitions were invalid under Oracle $v$. UsedSoft ${ }^{147}$ and therefore constituted unfair business practices, because they confused consumers about their rights. The German court disagreed, holding that the contractual resale prohibitions were not unfair. The court noted that Oracle $v$. UsedSoft was based on the E.U. Software Directive, relating to exhaustion of distribution rights, whereas the download of electronic books and music files constituted a "communication to the public" under the E.U. Copyright Directive, which is expressly not subject to exhaustion. ${ }^{148}$ Thus, the German court came out against a general digital first sale doctrine, just as a U.S. court did a few weeks later in Capitol Records v. Redigi. ${ }^{149}$

On April 17, 2013, the pendulum swung in the opposite direction, this time against software copyright owners. The U.K. Supreme Court held that loading a webpage does not trench on the reproduction rights of a copyright

145. See infra Subsection II.C.4.

146. As noted above, the Ninth Circuit in Vernor v. Autodesk, Inc., announced that its ruling applied across the board and was not limited to the software realm. 621 F.3d 1102 (9th Cir. 2010).

147. Case C-128/11, UsedSoft GmbH v. Oracle Int'l Corp., 2012 E.C.R. I-0000, 2012 O.J. (C 287) 16, discussed supra Part II.C.2.

148. Bielefeld Regional Court decision of March 5, 2013, see press release of the plaintiff, a German consumer protection center, at http://www.vzbv.de/11533.htm and the court decision at http://www.vzbv.de/cps/rde/xbcr/vzbv/LG_Bielefeld-E_Books-201303-05.pdf (both visited Nov. 23, 2014).

149. Capitol Records, LLC v. ReDigi Inc., 934 F. Supp. 2d 640 (S.D.N.Y. 2013). 
owner. ${ }^{150}$ Accordingly, a user who accesses a remotely hosted software copy via the internet and a locally cached copy of the software GUI does not require the software copyright owner's permission. Paired with the holding in Oracle $v$. UsedSoft, a software user may be permitted not only to resell a software copy to one secondary buyer, but to also make it available to thousands of software users as part of a cloud offering, if the same result can be technically structured in a manner that avoids additional copying of the underlying code. Again, we return to those considerations presently. ${ }^{151}$

\section{Departure from the statute's goals?}

The above rundown reveals severe climatic changes in recent decades. When adopted, software was slotted into the realm of "literary works" protected by copyright, so as to afford rights to proprietors while simultaneously reserving salient privileges to users. The safeguards of preexisting copyright law applied automatically-free alienability of tangible manifestations via the first sale doctrine and application of copyright's allpurpose defense, the fair use doctrine. In addition, the 1980 law that recognized software protection concomitantly relaxed the reproduction strictures applicable to this new domain, by virtue of the tailored addition of \117 to the statute.

Yet, as we have seen, Vernor and similar cases recognize plenary protection for software copyrights on the proprietors' side of the ledger, without any of the corresponding safeguards on the users' side. In particular, that Ninth Circuit case overtly denies application of the first sale doctrine, through the simple expedient of replacing "for sale" with "for license" in a single-pay transaction through which possession of tangible media changes hands forever. It also explicitly rejects application of the essential step defense, which is likewise a privilege belonging only to the "owner of a copy" of the software in question. ${ }^{152}$ And in that context, it even approves the elimination, through that "license," of the user's ability to reverse engineer the software in question ${ }^{153}$ - a privilege that the fair use doctrine itself grants,

150. Pub. Relations Consultants Ass'n Ltd. v. Newspaper Licensing Agency Ltd., [2013] UKSC 18.

151. See infra Part III.

152. Not only does Vernor extinguish privileges under the first sale doctrine, but its effect is equally devastating to users' coordinate privileges under the essential step doctrine. 621 F.3d 1102. See supra note 107.

153. As recited in the Ninth Circuit opinion, one provision in Autodesk's license stated, "YOU MAY NOT: (1) modify, translate, reverse-engineer, decompile, or disassemble the Software." Vernor, 621 F.3d at 1104. The Ninth Circuit expressly cited that limitation among the "use restrictions" that caused it to "conclude that [Autodesk's] customers are licensees of their copies of [the software in question] rather than owners." Id. at 1111-12. 
according to antecedent Ninth Circuit authority. ${ }^{154}$ In short, Vernor's tally is: Copyright Owners 4, Users $0 .{ }^{155}$

As we have further seen, there is no reason for John Wiley \& Sons and others similarly situated to remain aloof from Vernor's possibilities. Having lost Kirtsaeng at the Supreme Court level, those book publishers need only invest in a shrinkwrap machine to enclose all future inventory in a form contract proclaiming itself a "license." Not only can that expedient serve to bar importation of unwanted volumes, it can even ratchet up the publishers' rights to prevent loss of revenue occasioned by the existence of second-hand bookstores within the United States. ${ }^{156}$ The magical cellophane can even keep those volumes off of library shelves, ${ }^{157}$ so that the publishers would not have to make do with a single sale resulting in dozens of library patrons reading the same copy over time. ${ }^{158}$ In all those ways, they may now snatch victory from the jaws of Kirtsaeng's defeat.

Although book publishers would discover their newfound rights extinguishing users' privileges limited to the distribution right, their colleagues in the software business could push matters much further. Once it is established that a user in possession of a given physical product embodying

154. See supra Subsection II.A.3.

155. As set forth above, the metrics in place are: (1) copyright protection, (2) user's ability to resell, (3) user's ability to invoke $\int 117$, and (4) user's ability to invoke fair use.

156. To be sure, those bookstores could continue to sell old inventory. But, once the publishers wised up to labeling the distribution of their products a "license" rather than a "sale," future resale of the volumes in question would be rendered verboten.

157. Copyright owners have always lacked a library lending right under United States copyright law, of the sort that Canadian and Dutch law, for example, grant them. See 2 NimMER \& NimMER, supra note 62, \ 8.12[B][1][a] n.27 (citing International Copyright Law and Practice).

158. Those publishers need not stop even there. As set forth in the write-up by one of the current co-authors, a broad construction of Vernor frees book publishers to embody "use restrictions" on readers of affected volume from undertaking any of the following prohibited activities:

to read Chapter 5 before Chapter 4;

to read Chapter 6 more than three times;

to be seen reading the book in saloons or Bohemian redoubts;

to read multiple paragraphs aloud to a friend or relative;

to write a review of the book, absent pre-screening with the publisher, which has the unilateral right to veto any commentary not to its liking.

2 Nimmer \& NimMER, supra note 62, $\int 8.12[\mathrm{~B}][1][\mathrm{d}][\mathrm{i}][\mathrm{III}]$. The third item in the list derives from a parallel use restriction validated by the same panel that heard Vernor, in a companion copyright case. See MDY Indus., LLC v. Blizzard Entm't, Inc., 629 F.3d 928, 938-39 (9th Cir. 2010) ("The game must be used only for non-commercial entertainment purposes and may not be used in cyber cafes and computer gaming centers without Blizzard's permission."). 
software is not the "Owner" of that tangible object but rather only its "licensee," then not only are distribution rights lost under the first sale doctrine, but so likewise are reproduction rights under the essential step defense. ${ }^{159}$ Accordingly, a software purveyor may "license" copies of AutoCAD for $\$ 490$ per copy, and then turn around and sue the user for infringement the first time it dares to actually run the program by copying it into RAM. Granted, most extant End User License Agreements allow such running in RAM (in consonance with the dictates of $\int 117$ itself). ${ }^{160}$ But nothing forces copyright owners to be so magnanimous. In other words, those proprietors may provide explicitly that the copy that has been "licensed" for $\$ 490$ may never be run in RAM, absent additional conditions that the license imposes. ${ }^{161}$ Absent compliance, the subject reproduction through first-time running of the software in RAM becomes unlicensed, and hence infringing under Vernor's logic. ${ }^{162}$

If squarely presented with the issues just joined, it is conceivable that the U.S. Supreme Court would affirm the application of Vernor to all the above circumstances. It might reason that its decision in Kirtsaeng only construed the first sale doctrine, and that copyright owners remain free to fashion their own affairs by eliminating that doctrine entirely (along with the essential step

159. It should be recalled that the difference between computer programs and other species of literary works is such that "users risk infringement liability simply by running the very software copy they have acquired," a situation that Congress addressed "by targeted legislation" adding the "essential step" defense. See discussion infra Subsection II.B.2

160. To the extent that the EULAs are silent, an argument could arise that the doctrine of implied license privileges the user who has paid \$500 for a "licensed copy" of AutoCAD to run it in RAM. See 3 Melville B. Nimmer \& David Nimmer, Nimmer on Copyright \10.03[A][7] (2013). But the copyright owner can effectively extinguish any defense rooted in such an implied license by simply including an explicit term in the license, forbidding that conduct unless specifically authorized along the lines to be illustrated momentarily.

161. Those terms could be anything that the copyright owner cares to embody in the EULA, such as:

prior to loading software into RAM, the user must make a phone call to the software proprietor's headquarters to specify the exact location of the machine in question, followed by a subsequent phone call indicating that the session had ended;

prior to loading software into RAM, the user must pay an additional $\$ 500$; or

prior to loading software into RAM, the user must sign onto Facebook and "like" all items specified in the URL supplied by the copyright proprietor.

162. "The Copyright Act confers [the essential step] defense only on owners of software copies. See 17 U.S.C. \117 (2012). In contrast, a licensee's right to use the software, including the right to copy the software into RAM, is conferred by the terms of its license agreement." Vernor v. Autodesk, Inc., 621 F.3d 1102, 1112 n.13 (9th Cir. 2010). 
defense for software). If those proprietors simply shrinkwrap their goods with a form contract, the intended defenses of copyright law are set at naught. Indeed, even the cellophane expedient itself could be viewed as superfluous, with the license terms accomplishing their intended objective simply by virtue of being clearly delineated on the book's title page.

That hypothetical outcome certainly represents one possibility. But its contrary is more easily envisioned. After all, the Supreme Court's own seminal 1908 decision, later codified as the first sale doctrine, rejected the cogency of precisely such a purported "license" limitation on the book's title page. ${ }^{163}$ Viewed through that prism, it is straightforward to imagine the current Court rejecting the publishers' postulated end-run around Kirtsaeng. ${ }^{164}$

In short, the law is in flux. The marriage of copyright law to software protection has reached a state in which unforeseen developments have rendered the nuptial conditions suspect. Had Congress known in 1980 that software publishers would be able to unilaterally ratchet up their rightssuch that they would continue to enjoy complete copyright protection over their handiwork, untrammeled by the expected limitations of the first sale doctrine, essential step defense, and the quintessential matter of fair use $\mathrm{e}^{165}$ it is unclear whether Congress would have even gone forward to enact the amendment. These considerations suffice to warrant another look at the legal landscape. But the situation is actually even starker. To appreciate why, we must focus our attention on the cloud.

163. In Bobbs-Merrill Co. v. Straus, the legend read as follows: "The price of this book at retail is one dollar net. No dealer is licensed to sell it at a less price, and a sale at a less price will be treated as an infringement of the copyright." 210 U.S. 339, 341 (1908).

164. In Vernor, the Ninth Circuit postulated that "the Supreme Court in Bobbs-Merrill made explicit that its decision did not address the use of restrictions to create a license." 621 F.3d at 1114. In fact, by contrast, the Supreme Court overtly stated in that earlier case that the publisher in that case had limited the rights that it had "licensed." Bobbs-Merrill, 210 U.S. at 341. It then went on to state:

The precise question, therefore, in this case is, does the sole right to vend ... secure to the owner of the copyright the right, after a sale of the book to a purchaser, to restrict future sales of the book at retail, to the right to sell it at a certain price per copy, because of a notice in the book that a sale at a different price will be treated as an infringement, which notice has been brought home to one undertaking to sell for less than the named sum? We do not think the statute can be given such a construction ....

Id. at 350 .

165. "Although the traditional approach is to view 'fair use' as an affirmative defense, this writer, speaking only for himself, is of the opinion that it is better viewed as a right granted by the Copyright Act of 1976." Bateman v. Mnemonics, Inc., 79 F.3d 1532, 1542 n.22 (11th Cir. 1996). 


\section{ECONOMICS AND TECHNOLOGY OF THE CLOUD}

\section{A. Software Commercialization Models}

Software developers have always had numerous vehicles to exploit their innovations, including the following: ${ }^{166}$

- internal use: keep the software secret and use it internally as a competitive advantage for other business activities, e.g., manufacturing, financial services, administration, business planning, marketing, or product development;

- contract development. sell development services and work product, including title to the intellectual property rights to the software;

- distribution of copies: sell, lease, or give away copies of software (possibly subject to license agreements) to enterprises or consumers for a fee, to collect personal data, to establish a platform, or to generate goodwill in the open source community;

- distribution of hardware-software combinations: sell or lease products with pre-installed software, e.g., personal computers, enterprise servers, laptops, smart phones, etc.

In the first business model (internal use), the software developer does not make the software available at all. In the three other models, the developer transfers possession of software copies to users. Between these all-or-nothing cases regarding transfer of possession exists another group of business models, through which a software company retains physical possession of the software copies (and the hardware on which the software runs) and enables users to remotely access and use the software functionality. Such business models have been on the rise over the last fifteen years, under such names as application service providing ("ASP"), infrastructure-as-a-service ("IaaS"), platform-as-a-service ("PaaS"), and software-as-a-service ("SaaS"). ${ }^{167}$ More generally, they are known as "cloud" models, ${ }^{168}$ which is a term used throughout the remainder of this Article as a collective reference for service-based software exploitation models.

Economically, cloud models feature a number of aspects traditionally associated with services and leases, but without meeting all legal elements of

166. See generally Lothar Determann, What Happens in the Cloud: Software as a Service and Copyrights, 29 BERKELEY TECH. L.J. 1095 (2014).

167. See Ben Kepes, Understanding the Cloud Computing Stack: SaaS, PaaS, IaaS, RACKSPACE, http://www.rackspace.com/knowledge_center/whitepaper/understandingthe-cloud-computing-stack-saas-paas-iaas/ (last visited Oct. 9, 2014).

168. Lothar Determann, Data Privacy in the Cloud-Myths and Facts, 121 PRIVACY L. \& BUS. 17 (2013). 
these models. ${ }^{169}$ Similarly to both leases and services, cloud software users pay recurring fees and receive benefits during an agreed-upon, limited term. Unlike in traditional lease arrangements, however, the cloud user does not receive physical possession of software copies. The user is not responsible for maintaining the cloud offering (like a lessee typically would be in the context of a lease). The cloud user relies on the cloud provider with respect to software availability, operability, and data security. Unlike in the lease context, the cloud user does not return anything to the cloud provider at the end of the agreed term. Instead, the cloud provider returns the user's data.

And similarly to services, cloud users do not have to install, maintain, repair, or update hardware or software, or deal with interoperability. Unlike in traditional service arrangements, however, (e.g., word processing or outsourced accounting services), cloud users operate the software and create (and own ab initio) the work product generated with the cloud offering (e.g., Word documents, PowerPoint slides, Excel spreadsheets).

Cloud models do not resemble sales from an economic perspective. The cloud provider does not transfer possession to anything, the arrangement is not perpetual, and the user pays a recurring fee, rather than a one-time purchase price. Cloud models, like the internal use model, do not resemble sales. However, cloud models do not resemble the internal use model either. For example, the cloud provider does not use the software to support other business activities (such as manufacturing or other services). The software functionality is the service.

What advantages do cloud models have over the more traditional models summarized above? Software users obtain access to state-of-the-art software functionality without the burden of dealing with infrastructure, hardware, updates, maintenance, etc., which are not core competencies of many organizations. Also, change management (updates, upgrades, bug fixes) can be less burdensome for users. Users typically do not have to pay a large upfront sum in subscription models. Additionally, the overall costs of software and computing resources over time can be reduced as cloud providers bundle purchasing power and reduce redundancies by deploying computing capacity dynamically (i.e., only when needed by a particular user). To enjoy these benefits, more software users are willing to hand over their data to cloud providers, even though data security and third-party access to

169. See Ted Alford \& Gwen Morton, The Economics of Cloud Computing: Addressing the Benefits of Infrastructure in the Cloud, BOOZ ALLEN HAMILTON (2010), available at http://www.boozallen.com/media/file/Economics-of-Cloud-Computing.pdf (last visited October 9, 2014); The Economics of the Cloud, http://news.microsoft.com/download/ archived/presskits/cloud/docs/the-economics-of-the-cloud.pdf (last visited Oct. 9, 2014). 
data remain major concerns to some organizations. These concerns may be especially prevalent in less traditional business models. ${ }^{170}$

\section{B. EXAMPLES OF ClOUd OfFERINGS}

Cloud providers offer different commercial terms and various technological environments, for example, with respect to access (e.g., via third-party web browsers or proprietary thin client software downloaded on customers' computers), hardware configuration (e.g., one server for all customers hosted in multi-tenant data centers or one dedicated server and facility per customer) and software architecture (e.g., one copy in RAM serves multiple customers or each customer accessing the remote offering causes a separate RAM copy to be created). Offerings depend on the provider's business model, on whether the provider develops its own software or largely uses programs made by other companies, and on other factors. ${ }^{171}$ A given cloud provider may offer third-party software application products (such as Microsoft Word, Microsoft PowerPoint, or Adobe Acrobat) to enterprise and consumer customers. ${ }^{172}$ Another may host thirdparty computer games or components thereof. ${ }^{173}$ Yet other providers develop and host their own enterprise applications for customer relationship management, human resources systems, or enterprise resource planning. ${ }^{174}$

Our analysis herein refers to a simplified, typical, technical scenario: the cloud provider acquires software copies by developing them internally or procuring them from outside sources. Then, the cloud provider creates the cloud offering by combining application programs with operating system software, drivers, and programs that facilitate remote access. The cloud provider installs the software combination on server hard disks in secure locations with connections to the internet. When the cloud provider turns the cloud service on, it uploads a software copy into the RAM of one or more servers for its customers to use.

Customers enter into an agreement with the cloud provider, pay a recurring fee, and receive access credentials (user IDs and passwords).

170. Lothar Determann, Data Privacy in the Cloud: A Dozen Myths and Facts, 28 COMPUTER \& INTERNET LAW. 11, 1 (2011).

171. Such as software functionality, industries, targeted user groups (enterprise, consumers, prosumers, etc.).

172. See, e.g., ONLIVE, http://www.desktop.onlive.com/ (last visited Dec. 13, 2014).

173. See generally MDY v. Blizzard Entm't, Inc., 629 F.3d 928 (9th Cir. 2010).

174. See, e.g., SALESFORCE.COM, INC., http://www.salesforce.com/ (last visited Dec. 13, 2014); SUGARCRM, http://www.sugarcrm.com (last visited Oct. 13, 2014); WORKDAY, INC., http://www.workday.com/ (last visited Dec. 13, 2014); NETSUITE INC., http://www.netsuite.com/ (last visited Dec. 13, 2014). 
Customers can then access the cloud offering with general-purpose web browsers (e.g., Firefox, Chrome, Safari, or Internet Explorer). The work product that the customer creates with the cloud offering consists of data (e.g., in the form of a PowerPoint slide deck or Word document) stored on the cloud provider's server. The customer can view the work product via the GUI that is reproduced via the web browser on the remote computer. If the customer downloads (i.e., copies) the work product to its remote computer, the cloud provider's server may deliver the work product in files that contain standard file format specifications to enable the user to process the files on remote computers. If the cloud provider's offering includes objects for inclusion into work product (e.g., clipart for PowerPoint slides), customers can view or download copies of such objects, too.

\section{Multiple Cloud Users}

Cloud service providers can configure their software such that one RAM copy can simultaneously serve multiple users. In a multi-tenant, multithreaded setup, dozens or even thousands of users can use the same RAM copy without the need to create additional copies of the application software that provides the program functionality on the remote users' computers. Does that activity implicate the copyright owner's rights? We begin with the core reproduction right, ${ }^{175}$ and then radiate outward to consider the other rights belonging to the proprietor. ${ }^{176}$

Counting copies for the purposes of copyright law analysis produces the following results: a company that offers software as a service via the cloud typically must create two copies. Included are one permanent copy of the underlying code on its server and one RAM copy in the working memory. In that regard, the cloud scenario does not involve more copies than a traditional desktop scenario. ${ }^{177}$ However, in the cloud context, the one RAM copy can be accessed by multiple users_-very much unlike the desktop scenario.

In the usage phase, once the cloud solution is up and running, users make access requests from remote computers. Each time the software is executed, numerous fractional excerpts of the RAM copy are reproduced in cache memory spaces and the CPU of the cloud provider's server. As in the desktop scenario, such fractional excerpts of the RAM copy do not implicate the software owner's reproduction right. ${ }^{178}$ Instead, the individual command

175. See 17 U.S.C. \ 106(1) (2012).

176. See id. 106(2)-(6).

177. See supra Subsection II.B.2.

178. See supra Subsection II.B.2. 
lines reproduced in the $\mathrm{CPU}$, or cache registers close to the CPU, tend to be too fleeting to count as copies, too small to show originality, and too functional to constitute protectable expression. ${ }^{179}$ Thus, in the context of cloud offerings, two copies can serve far more users than in the desktop context.

We must further consider whether users' viewing of GUIs on remote computers increase the copy count. In the cloud context, users can never see the software itself, which stays hidden on the cloud provider's server (on hard disk, in RAM, cache, and CPU). Many computer programs do not embody any meaningful GUI, so their analysis ends without any additional copies added to the count. For programs that do embody a meaning GUI, however, multiple remote users can see the GUI of the software. In response to access requests, the cloud provider sends copies of HTML code to display the software's GUI on each remote computer. Thus, there can be one GUI copy per remote user. Are more actionable reproductions thereby implicated? The answer is often negative, as such GUI copies may not "count" for purposes of copyright infringement. The first reason for this conclusion is that many GUIs are bare of copyrightable material. After all, GUIs tend to be highly functional and uniformly aligned with formats in the public domain to accommodate user expectations. But even when dealing with the exceptional GUI that reflects a creative contribution of expression, a cloud provider could avoid displaying it remotely by suppressing it. Specifically, the cloud provider need only prepare its own add-on GUI to mask the original GUI. This superimposition need not impair the software's functionality, as the GUI is not software per se, but rather is the output of software. ${ }^{180}$

Thus, cloud scenarios permit a far greater number of users to utilize one software copy without requiring more copying more than in the traditional desktop scenario. Consequently, cloud scenarios do not implicate copyright owners' reproduction rights any more than in the desktop scenario, even when the user of a single software copy installs it on a cloud server for use by thousands of other users.

Cloud scenarios likewise often will not implicate the copyright owner's other rights. ${ }^{181}$ Regarding the adaptation right, ${ }^{182}$ cloud providers at times may have to modify code that was not originally written for cloud

179. See supra Subsection II.B.2.

180. See supra Subsection II.A.3-4.

181. For a more expansive treatment of these issues, see generally Lothar Determann, What Happens in the Cloud: Software as a Service and Copyrights, 29 BERKELEY TECH. L.J. 1095 (2014).

182. See 17 U.S.C. $\$ 106(2)(2012)$. 
deployment. However, if the provider can deploy the remote-access functionality with independently created programs, neither the cloud provider nor its end users would seem to implicate the software owner's adaptation right. ${ }^{183}$ Moreover, whatever combinations or modifications may occur in RAM or CPU cache do not seem to reach sufficient levels of creativity or fixation to amount to adaptation. ${ }^{184}$ Thus, if the software supplier delivers software in "cloud-ready" form or if the cloud provider can achieve "cloud-readiness" with independently created or licensed programs, the underlying programs' adaption right should not be implicated. Turning to the distribution right, ${ }^{185}$ the cloud provider does not transfer copies of the implicated software to the customer's computer-neither complete copies stored on ROM, nor partial copies stored in RAM or in cache. Instead, all copies remain on the cloud provider's server. ${ }^{186}$ Accordingly, the cloud model should not implicate the distribution right of the underlying programs, either.

Regarding public performance rights, ${ }^{187}$ the Act teaches that

[t]o "perform" a work means to recite, render, play, dance, or act it, either directly or by means of any device or process or, in the case

183. Specific cases might hinge on how much the underlying program had to be modified, as opposed to how much new expression the Cloud provider needed to achieve remote access functionality.

184. Arguably to the contrary of that perspective is Dun \& Bradstreet Software Services, Inc. v. Grace Consulting, Inc. 307 F.3d 197, 204 (3d Cir. 2002) (holding that a software company distributing independently developed software modules for use with another software company's software program infringes the other company's copyrights because copies of the module and program are merged in computer memory and thus create a derivative work). But, this case does not seem to reflect a widely shared perspective. See generally Determann, supra note 1, at 1443 et seq. Moreover, if the case does state good law, its holding would equally affect software combinations in desktop-type deployments and therefore, the questions it raises are not peculiar to the Cloud.

185. See 17 U.S.C. $\$ 106(3)$ (2012).

186. In the cloud context, customers do not even possess new copies of the code. Instead, those customers can only download the output that they create with the software (e.g., Word documents, PowerPoint slides, Excel spreadsheets) to their own computers. They cannot obtain copies of the software that runs on the cloud provider's servers to create the output (e.g., Microsoft Word, PowerPoint, or Excel application software). See Michael P. Widmer, Application Service Providing, Copyright, and Licensing, 25 J. MARSHALl J. COMPUTER. \& INFO. L. 79, 95 (2007).

187. See 17 U.S.C. $\int 106(4)$ (2012). Note that this right is inapplicable to certain types of copyrightable works. But it does apply to "literary . . . works," and therefore encompasses software. The Copyright Act also embodies another right of public performance, applicable only to sound recordings. See id. $\ 106(6)$. As that subject matter is distinct from the instant subject, this Article confronts that matter no further. See 2 Nimmer \& NimmER, supra note $62, \int 8.22$. 
of a motion picture or other audiovisual work, to show its images in any sequence or to make the sounds accompanying it audible. ${ }^{188}$

The enumerated activities (recite, render, play, dance, act) all require that the work in question be presented to a human audience in a manner that can be visually or audibly perceived. By contrast, a computer's internal execution of code does not cause or allow perception by a human audience. ${ }^{189}$ Therefore, a quick answer ${ }^{190}$ is that the performance right of the underlying programs likewise should not be implicated by the cloud model. Finally, regarding the public display right, ${ }^{191}$ any material displayed remotely ${ }^{192}$ on users' screens (outside of the GUI, which can simply be replaced as discussed above) ${ }^{193}$ is unlikely to amount to copyrightable expression sufficient to warrant an infringement cause of action. ${ }^{194}$ Therefore, it seems overwhelmingly likely

188. 17 U.S.C. $\int 101$ (2012).

189. Of course, software designed to run a video game could be performed. Likewise, software that embodies video or audio tutorials could see those aspects streamed, which in turn would create a public performance. The discussion in the text above is extremely cursory. Consider the following counterpoint:

At best, defendant Yeo's alleged publication of the ChainRxn video game for play by Facebook users constituted a public performance of plaintiff's copyrighted work under 17 U.S.C. \106(4). Just as Congress considered the "reading a literary work aloud" as a performance rather than display of a literary work, the reading of Boomshine's copyrighted source or machine code by a computer (resulting in the presentation of the video game to the user) could be seen as an analogous performance of the underlying work. See H.R. REP. No. 94-1476, at 63 (1976). Admittedly, this area of the law is still developing.

Miller v. Facebook, Inc., No. C 10-00264 WHA, 2010 WL 2198204 (N.D. Cal. May 28, 2010).

190. Bearing in mind the caveats of the previous footnote, the Ninth Circuit has held that merely playing interactive video games in public cannot implicate public performance rights because the concept of playing as performance had been narrowly interpreted to apply only to films and music. Allowing copyright owners games to control if and where games are played would unreasonably strengthen the copyright owners' interests at the expense of public interests in access to games. See Allen v. Academic Games League of Am., Inc., 89 F.3d 614 (9th Cir. 1996).

191. See 17 U.S.C. \106(5) (2012).

192. Regarding the public display that occurs "at the place where the copy is located," such public display is immune from copyright liability under an extension of the first sale doctrine. See id. \$109(c).

193. See supra text preceding note 183 .

194. U.S. courts have denied copyright protection for command line arrangements in office software products because these arrangements constitute methods of operation, which are excluded from copyright protection. See Lotus Dev. Corp. v. Borland Int'l, Inc., 49 F.3d 807 (1st Cir. 1995), aff'd by an equally divided Court, 516 U.S. 233 (1996). Similarly, commonly used icons and symbols lack sufficient originality or are dictated by extrinsic factors (user 
that the cloud model does not implicate the underlying program's public display rights.

The foregoing considerations introduce new dynamics. In theory, they create a tremendous risk to software copyright owners, which may no longer have the power to force each user to acquire her own copy. Instead, the cloud provider may be able to simultaneously service many users. In the United States, at least, Vernor and its progeny may mitigate this risk by magnifying such owners' rights. To the extent that software purveyors continue to succeed in establishing that they only "license" those copies, they can simply insert a clause prohibiting cloud exploitation into the "license" terms. In that manner, contract law will step in to minimize their loss of rights under copyright law. ${ }^{195}$

Nonetheless, these cloud-prohibition clauses do not shrink the concerns of software owners into insignificance. First, as we have seen above, European law regularly views software copies as being "sold" rather than "licensed." Therefore, the lenity of U.S. law cannot apply there. ${ }^{196}$ Second, U.K. law magnifies users' freedom by not requiring copyright owners' consent to reproduce even highly creative websites or GUIs. ${ }^{197}$ Third, danger to copyright owners is not altogether absent in the United States because not all courts follow Vernor. Moreover, the Supreme Court may reconsider Vernor's holding if the occasion arises. ${ }^{198}$ Fourth, even if no chinks ever develop in Vernor's armor, a proprietor may surrender possession of a given copy, for whatever reason, outside of license terms. ${ }^{199}$ A cloud purveyor would only need one copy to take advantage of the various features

expectations and familiarity). See Apple Computer, Inc. v. Microsoft Corp., 35 F.3d 1435 (9th Cir. 1994).

195. Of course, to be efficacious, the subject terms must constitute a condition to the license, rather than a covenant. That distinction proved fatal to the copyright claim in MDY $v$. Blizzard, the companion case to Vernor that was referenced above. See supra note 141. Specifically, copyright owner Blizzard in that case sought to impose liability on counterdefendant MDY. It failed in that endeavor when the Ninth Circuit interpreted the provision under investigation to be a mere covenant, whose violation accordingly did not give rise to an infringement claim. See MDY Indus., LLC v. Blizzard Entm't, Inc., 629 F.3d 928, 939-42 (9th Cir. 2010).

196. See supra Subsection II.C.2.

197. Id.

198. See supra Subsection II.C.1.

199. One could imagine a beta copy that was not shrinkwrapped, settlement of litigation that leaves a copy in a remote party's hands, a mistake at the factory that causes product to be shipped absent its shrinkwrap terms or printed defectively, or a variety of other factors. 
catalogued above without triggering copyright infringement liability, despite making the third-party's software accessible to thousands of third parties. ${ }^{200}$

\section{THE CLOUD'S IMPACT ON SOFTWARE COPYRIGHTS}

Based on the above review of past challenges relating to software and copyrights, along with the development of cloud exploitation models, the stage is set to assess the cloud's impact.

\section{A. Challenges to COPYRight LAW'S gOALS}

We have seen above how an aggressive implementation of Vernor could set at naught the delicate balance underlying software protection. In particular, it could undermine the first sale doctrine, the essential step defense, and the application of fair use to software. ${ }^{201}$ Still, the discussion has also noted that aggressive implementation might not pass legal muster-in other words, the Supreme Court might halt Vernor's advance before matters reached such a pass, at least in the context of traditional book publishing. ${ }^{202}$

Nonetheless, one must frankly concede that no such ameliorative construction seems likely in the cloud context. Each possible defense is examined in turn.

\section{First sale doctrine}

A software copyright owner can avoid the first sale doctrine by commercializing its software as a service rather than as a sale. Cloud service transactions involve recurring payments, temporal-use limitations, and no transfer of possession. Such transactions do not resemble sales by any standard. Besides moving to services models, software copyright owners have a few other options to reduce the risk that the first sale doctrine applies, even under E.U. laws. Software companies can include "sales-unlike" clauses in contracts, ${ }^{203}$ apply technological restrictions, ${ }^{204}$ charge extra for re-sales or

200. Other pitfalls also loom, such as the distinction between covenant and condition if the operative cause of action is for copyright infringement, and lack of privity if the operative cause of action is breach of contract. See supra note 195.

201. See supra Section II.B.

202. See supra Subsection II.C.3.a.

203. See Determann \& Batchelor, supra note 118 (noting that software companies can consistently use terminology to clarify that they are selling licenses, services, or access to software, rather than software copies. They can include "unlike-sales" commercial terms, "field-of-use" restrictions, a contractual obligation to return old software copies at the time of upgrades, access limitations (authorized or concurrent users), and others).

204. Software that is frequently updated, upgraded, and changed, without reverse version interoperability, is more difficult to resell-but may also be less attractive to users. Dongles and expiring activation codes can also be used to control changes on the end-user 
transferable licenses, charge more for support on transferred licenses, grant "real" reproduction licenses that cannot be transferred based on the exhaustion principle (e.g., enterprise licensing), etc. However, with a shift to cloud models, copyright owners could preclude secondary markets more clearly and effectively.

This state of affairs generally corresponds to Vernor's ruling. Nonetheless, the differences are as important as the points of commonality. First, and most importantly, Europe applies the opposite construction. ${ }^{205}$ Nonetheless, the cloud would Americanize the content of European law in this regard. By moving to cloud business models, a software copyright owner could continue to control distribution of its software and side-step any first sale under E.U. law.

Second, internal to United States law, the cloud eliminates any conceptual cloud hanging over Vernor's construction. As previously explicated, the problem with the Ninth Circuit's logic inheres in the Ninth Circuit's construction that a proprietor's permanent parting with physical ownership for a one-time fee does not constitute a sale. ${ }^{206}$ Nonetheless, even Vernor's harshest critics concede that the cloud does not result in a sale of physical products. ${ }^{207}$ In other words, when a user does not obtain permanent dominion over CD-ROMs containing AutoCAD, but instead rents access to that software product by the hour, all parties agree that no "sale" has taken place. Accordingly, the cloud itself affords no room to vindicate the ruling of earlier cases to the contrary of Vernor. ${ }^{208}$

Third, the aggressive extension of Vernor under current copyright law to books, as postulated above, seemed dicey at best. ${ }^{209}$ By contrast, purveying ebooks over the cloud is straightforward and beyond challenge. In the ebook context, users do not gain dominion over physical products that the first sale doctrine would allow them to resell. ${ }^{210}$ Accordingly, a user privilege that traces back to 1908 and is currently codified in $\int 109$ of the Act, could effectively be eliminated. The upheaval to traditional notions of copyright law could not be more pronounced.

\footnotetext{
side, regarding hosting equipment, authorized users, and other details-but such restrictions are not favored by end users or data privacy laws.

205. See supra Subsection II.C.2.

206. See supra Subsection II.C.1.

207. See 2 NimMER \& NimMER, supra note 62, \8.12[B][1][d][iii].

208. See supra note 97.

209. See supra Section II.C.

210. See 2 Nimmer \& NimMER, supra note 62, \8.12[E] (no digital first sale defense).
} 
On the other hand, a move towards embracing the first sale doctrine as radically as UsedSoft suggests could cause the cloud to extremely marginalize the software copyright owner's rights and economic opportunities. Under UsedSoft, once a software developer parts with one software copy under an agreement characterizing the transaction as a non-exclusive, limited license, a licensee-turned-owner could deploy the copy over the cloud and offer it to thousands of other users in competition with the software developer. ${ }^{211}$ If U.S. courts do not follow UsedSoft or employ European views on copy ownership in cross-border cases, ${ }^{212}$ cloud providers might find a home in Europe for cloud offerings. These providers might deliver cloud offerings remotely to users in the United States without actually causing copies to be made in the United States, disrupting legitimate U.S. copyright exploitation in the process.

\section{Essential step defense}

The previous subsection illustrated how copyright owners can unilaterally eliminate users' distribution privileges by purveying their wares on the cloud. Different considerations apply if this state of affairs is extended to users' reproduction privileges in software. The aggressive application of Vernor postulated above imagined that copyright owners of software would charge $\$ 490$ to "license" a physical copy of software, and then impose an additional charge to use it (e.g., by loading it into RAM). How do those aspects translate to the cloud?

As a theoretical matter, danger exists that this aspect of users' privileges will equally be forfeited. As a practical matter, however, there is reason to be more sanguine. Granted, cloud purveyors can impose any charges that the market will bear-for instance, $\$ 2$ for the first four hours of using Program $\mathrm{X}$, and then $\$ 1000$ for every minute thereafter. Yet it is doubtful that purveyors will be able to charge for "licensing" a physical copy of the software, only to impose a hidden "use" charge later. After all, there is no physical copy provided at the outset to entice users to pay. In other words, the charge will most likely be for use, not licensing. The same potential for abuse ventilated above seems to be largely absent regarding the essential step defense.

\section{Reverse engineering}

An aggressive application of Vernor also elicits different considerations when applied to the fair use defense's protection of reverse engineering. In

211. See supra Section III.C.

212. See Importing Software and Copyright Law, supra note 114, at 4-5. 
this context, reverse engineering means the process of copying, analyzing, and disassembling object code in order to separate unprotectable, functional elements from a copyrightable expression. The cloud, however, appears to make traditional forms of reverse engineering impracticable. ${ }^{213}$ This state of affairs results not so much from limitations established by copyright law, but rather from the cloud provider's technological ability to control and restrict access to the underlying code residing on the cloud provider's server. ${ }^{214}$ In other words, in the cat-and-mouse competition between software publishers and competitors, the latter have previously been able to reverse engineer, given the business models and technical controls available. The advent of the cloud promises to overturn this power imbalance.

Of course, future competitors could attempt self-help by removing the software publishers' technical measures and attempting to reverse engineer the product anyway. Unfortunately for them, however, those who attempt to reverse engineer software underlying cloud offerings face civil and criminal penalties under laws prohibiting unauthorized access to computers and circumvention of technical protection measures. These protections and penalties are codified in the Digital Millennium Copyright Act, ${ }^{215}$ the Computer Fraud and Abuse Act, ${ }^{216}$ and equivalent laws in the E.U. ${ }^{217}$

These same kinds of laws - protecting computers against interferencecan be used to both prevent the creation of interoperable software products through reverse engineering, as well as establish absolute hurdles against interoperability of independently created software programs. In the age of the cloud, software offered as a service on one computer often may access software offered as a service on another computer in order to communicate data. Such access can be hindered based on laws restricting computer interference and circumvention of technical protection measures. ${ }^{218}$ Courts have rejected arguments by defendants that the fair use doctrine under copyright law must allow them access to hosted software copies, in

213. See Craig Zieminski, Game Over for Reverse Engineering?: How the DMCA and Contracts Have Affected Innovation, 13 J. TECH. L. \& POL'Y 289, 307-09 (2008).

214. In addition, the pertinent contracts promulgated by the cloud provider can be to the same effect.

215. See 17 U.S.C. $\int 1201$ (2012).

216. See 18 U.S.C. $\$ 1030$ (2012).

217. See Ian Walden, Computer Crimes AND Digital Investigations (2007); see also Lothar Determann, Internet Freedom and Computer Abuse, 35 HASTINGS COMM. \& ENT. L.J. 429 (2013) (discussing the history, context and current reform proposals regarding computer interference laws in the United States and abroad).

218. See MDY Indus., LLC v. Blizzard Entm't, Inc., 629 F.3d 928, 945 (9th Cir. 2010); Craigslist Inc. v. 3Taps Inc., 942 F. Supp. 2d 962 (N.D. Cal. 2013) (finding violations of the DMCA's anti-circumvention measures by automated access to websites). 
derogation of the website operator's terms of use or in violation of technical protection measures, even if the online access was for the purpose of developing or deploying interoperable applications. ${ }^{219}$ Therefore, cloud providers can largely rely on technical protection measures and contractual website access restrictions to protect the underlying code. Once such measures and access restrictions are in place, others cannot access the software underlying the cloud offering, except in compliance with the authorizations contained in the applicable contracts.

Therefore, the move to cloud models may potentially result in less interoperability and adverse effects on innovation. Whether this potential will materialize remains to be seen. Currently, many cloud platforms encourage the development of compatible applications and have spurred a flurry of development. $^{220}$ On the other hand, frictions have developed and software copyright owners with established platforms have been able to prevent the development of add-on offerings that they probably could not have achieved under more traditional distribution models. ${ }^{221}$ If this situation becomes a problem and significantly stifles innovation, changes to the legislative framework may have to be considered, including similar defenses for access and reverse engineering of software for interoperability purposes in the cloud, as in more traditional distribution models.

\section{B. OTHER IMPACTS}

Of course, the cloud also poses challenges to other aspects of copyright law.

219. See MDY, 629 F.3d at 950; Ticketmaster L.L.C. v. RMG Techs., Inc, 507 F. Supp. 2d 1096 (C.D. Cal. 2007) (development, hosting, distribution, and/or use of software designed to access Ticketmaster website for bulk ticket purchases in circumvention of contractual and technical access restrictions constitutes copyright infringement in Ticketmaster's web pages and violation of the Computer Fraud and Abuse Act); Facebook, Inc. v. Power Ventures, Inc., 844 F. Supp. 2d 1025, 1028 (N.D. Cal. 2012) (automated access to Facebook pages for marketing purposes in violation of Facebook terms of use constitutes a violation of the Computer Fraud and Abuse Act and copyright infringement); Lothar Determann \& Irene Gutierrez, Copyright Violations in Caching Website Content, Contract Formation, 3 J. INTELL. PROP. L. \& PRAC. 548 (2008); Zieminski, supra note 213.

220. See, e.g., APPLE APP STORE, http://www.apple.com/iphone/from-the-app-store/ (last visited December 13, 2014).

221. See, e.g., Ticketmaster, 507 F. Supp. 2d 1096; Determann \& Gutierrez, supra note 219; MDY, 629 F.3d at 945. 


\section{Open-source-license terms}

Today, most commonly used open-source license terms permit reproduction and adaptation freely and unconditionally. ${ }^{222}$ In order to preserve developers' freedom to tinker with code, the license terms typically refrain from applying any restrictions until the developer distributes a copy to third parties. ${ }^{223}$ Consequently, companies that operate service businesses have been able to use most open-source code without being legally obligated under the applicable license terms to give back to the community. ${ }^{224}$ Cloud models sidestep some of the attempts by the open-source movement to keep software free and available. In cloud models, however, the code is locked up on servers and not available for further improvement and development.

This matter presents a choice to the drafters of open-source license terms. Licensors can tie release obligations or other restrictions not only to distribution, but also to offering modified or unmodified software as a service, given that cloud offerings always implicate reproduction rights. ${ }^{225}$ The GNU GPLv3 (Affero version) already embodies such a provision ${ }^{226}$ and other licenses may follow suit. ${ }^{227}$ Thus, the move to service models may prompt some open-source code licensors to consider updating their license terms. In the meantime, companies can sidestep most commercial concerns relating to open or free software code by switching from traditional forms of software distribution to cloud models.

\section{Unauthorized Access to Copyrighted Material}

a) Piracy

Software pirates around the world blatantly copy literal code without the copyright owner's authorization. ${ }^{228}$ This problem significantly afflicts software commercialization models that are based on delivery of software

222. See The Open Source Definition, OPEN SOURCE INITIATIVE, http://opensource.org/ osd/ (last visited Dec. 13, 2014) ("Free Redistribution: The license shall not restrict any party from selling or giving away the software ... The license must allow modifications and derived works ....")

223. See, e.g., Sections 0 and 2, GPL, http://www.gnu.org/copyleft/gpl.html (last visited Dec. 13, 2014).

224. See Theresa Gue, Triggering Infection: Distribution and Derivative Works under the GNU General Public License, 2012 U. ILL. J.L. TECH. \& POL'Y 95 (2012).

225. See supra Part III.B.

226. GNU Affero General Public License, GNU OpERATING SYS., http://www.gnu.org/ licenses/agpl-3.0.html (last visited Dec. 13, 2014).

227. Gue, supra note 224, at 101.

228. Bus. Software Alliance, Shadow Market: 2011 BSA Global Software PIRACY STUDY (9th ed. 2012), available at http://portal.bsa.org/globalpiracy2011/. 
copies on physical media or by way of download. ${ }^{229}$ In the cloud context, pirates find it much more difficult to obtain software copies, given that the code remains on heavily secured servers and is not widely disseminated. ${ }^{230}$ In the best case scenario, cloud offerings will undermine much of the very incentive underlying piracy, as users are afforded the ability to obtain the works they want when they want from wherever they are located-all for (hopefully) a reasonable price. ${ }^{231}$

Nonetheless, the software copyright owners' economic interests can be adversely affected by cloud customers' sharing of access credentials in violation of cloud agreements, or by criminals hacking into cloud systems. ${ }^{232}$ At present, those activities seem easier to prevent and prosecute than literal reproduction of physical software copies. Therefore, hosted software in cloud models tends to be far less vulnerable to software piracy than in more traditional distribution models. ${ }^{233}$

\section{b) Facilitation of Multiple Cloud Users}

Copyright owners are separately threatened by the cloud's ability to disseminate software to numerous third parties. A user who obtains one physical copy of that software can offer access to it, via the cloud, to tens of thousands of third parties, thus obviating the need for any of those myriad end-users either to obtain their own copy or to access the proprietor's own cloud offering. Viewed through that prism, the cloud portends disaster to those copyright owners. Any positive influence the cloud has on rightsholders' bottom line through universalizing the effects of Vernor are more than counterbalanced by the dangers of cloud exploitation escaping copyright liability. ${ }^{234}$

229. See, e.g., Piracy, Microsoft, http://www.microsoft.com/en-us/piracy/default.aspx (last visited December 13, 2014).

230. See Matt Asay, The BSA's Fading Twentieth-Century Piracy Fight: Misreading the Data, REGISTER (Sept. 24, 2010), http://www.theregister.co.uk/2010/09/24/piracy_open_ source_bsa/.

231. "Combining cloud computing and content streaming technologies could thus reduce online piracy of entertainment content by providing the consumer with value-the ability to access content from almost anywhere-while providing content owners, creators, and providers with an unprecedented means to control their digital works." Tamara Celine Winegust, Work with Your Head in the Clouds: The Impact of Cloud Computing and Content Streaming on Copyright in the Entertainment Industry, 4 AM. U. INTELL. PROP. BRIEF 8, 10 (2012).

232. See Florence de Borja, Can Cloud Computing Stop Software Piracy?, Cloud TimeS (Sept. 7, 2012), http://cloudtimes.org/2012/09/07/can-Cloud-stop-software-piracy/.

233. See Asay, supra note 230.

234. See supra Section III.C. 
As noted above, the legal underpinnings of that model have yet to be fully clarified. ${ }^{235}$ Much may depend on the precise technical specifications employed by various cloud purveyors, as well as how many distinct copies they need to generate to service their customers. At present, all that can be stated is that dangers and opportunities abound for all interested parties.

\section{SOME WEATHER FORECASTS}

With the benefit of the foregoing exposition, it is time to evaluate the cloud and its implications for copyright on software and beyond. Given that the phenomenon is still at its outset, the time is premature for a marriage counselor to conclude either that there are irreconcilable differences or that a bit of effort on both parties' sides will ensure another three decades of at least tolerable cohabitation. The savvy observer must simply register current tensions in light of past history, extending strictly tentative diagnoses regarding the balms needed for future non-violent relations.

A. Gloomy Prospects: Dark Clouds Undermine the GoAls of 1980

RESOLVED, The cloud is unprecedented, both in its technology and the stress that it places on traditional copyright categories.

Congress embraced software within the copyright domain, faute de mieux, and subject only to a carefully developed balance: at the same time that it conferred rights on copyright under $\int 102$ of the Copyright Act, it adopted the limitations on the distribution right in $\int 109$; equally, Congress added new limitations on the reproduction right under $\int 117$, acting against the backdrop of copyright law's ubiquitous defense, the infinitely malleable fair use doctrine.

As set forth above, certain interpretations of existing law (celebrated by some, bemoaned by others) yield a tally of Copyright Owners 4, Users 0 . $^{236}$ For those who bemoan those results, at least current law contains some prospect for amelioration. Given that these critics decry Vernor's construction of the statute as faulty, they hold onto the hope that other circuits, eventually joined by the Supreme Court, will ultimately jettison that ruling and set the law back on its proper course.

No such hope arises, however, as to the cloud. Even Vernor's critics concede that those who purvey software via the cloud may invoke existing law to eliminate any user privileges of further distribution. Moreover, they

235. See supra Section III.C.

236. See supra Subsection II.C.4. 
may equally deny any user privileges of further reproduction, albeit that particular danger is noticeably muted in the cloud context. Finally, cloud offerings effectively lie beyond the realm of fair use exploitation. As such, all use becomes "fared," 237 with no latitude remaining for one of the fundamental protections encapsulated in the text of the 1976 Act itself. ${ }^{238}$

These deformations push the law so far out of its intended path that reformation becomes essential. As the Vice-Chair of CONTU commented in the report on which Congress relied when extending copyright protection to software in 1980, certain "line[s] of demarcation" must be borne in mind, not because they were needed as of 1978 when the CONTU report issued, but rather because they "may prove useful in the years to come if the current recommendation for protection of all software should prove unduly restrictive." 239

That time has now dawned. The cloud is its midwife.

In fact, the cloud's deformation is much worse than even the Vice-Chair of CONTU imagined three-and-a-half decades ago. For not only does the cloud eliminate the first sale doctrine as to software, but it also exerts the same effect across the field of all literary works. Since 1908, Bobbs-Merrill Co. $v$. Straus and its statutory codification have safeguarded the privilege for readers of novels to resell them at second-hand bookstores. In a world of ebooks, that privilege is no more.

The same deprivation applies across the board, moreover, beyond the sphere of literary works. Video rental stores have traditionally offered movies to their customers. That instantiation serves for audiovisual works the role that libraries have traditionally served for literary works. Those outlets will be similarly barred in the cloud's universe. And the same applies to music and other works subject to copyright protection as well. In fact, the only secondary market for works of authorship, in a future dominated by the cloud, promises to be in the realm of fine art. Thus, purchasers of a painting to hang on their living room wall will be able to resell the work, as will the sculpture garden that wishes to cycle out an old maquette for a new bronze. $^{240}$ Outside those peripheral applications, however, the first sale doctrine will be rendered otiose everywhere.

237. See Tom W. Bell, Fair Use vs. Fared Use: The Impact of Automated Rights Management on Copyright's Fair Use Doctrine, 76 N.C. L. REV. 557 (1998).

238. See supra note 165.

239. See FINAL CONTU REPORT, supra note 29.

240. But even those resales will become more complicated, to the extent that the Copyright Act is amended to adopt the droit de suite, a prospect currently under consideration. See Resale Royalty Right, 78 Fed. Reg. 19326 (Mar. 25, 2013). 
Thus the dream of those "license" advocates ${ }^{241}$ who, long ago, rendered the first sale doctrine a dead letter will be universalized. In their wake, Fred Hoyle's dystopian vision becomes our reality. ${ }^{242}$ To save us from that darkness, legislative redress is needed.

\section{B. A CHEERY RebutTAl: RetURN tO AN EARLIER SENSIBILITY}

RESOLVED, The cloud is not unprecedented and simply returns many traditional copyright categories to their historic role.

On the other hand, a broader view of history yields different insights. We change our field of vision here from the "literary works" that have occupied this Article thus far-whether those denominated software or more traditional forms, such as novels - in order to scrutinize the realm of music. Here, we reach different territory.

Whereas Bobbs-Merrill Co. v. Straus litigated the status of The Castaway over a century ago, at a time when any interested reader could obtain her own personal copy of the work in question, matters were simultaneously very different for music lovers.

Throughout most of history, music has been experienced exclusively as a service, or something that one needs to receive from a service provider in order to enjoy. The advent of sound recordings-especially digital sound recordings-commoditized the medium, allowing consumers to take music with them wherever they go, as well as giving them the ability to manipulate and engage with the sound recordings at will. "Internet music streams, however, remove consumers' control over the access and playback of music, transforming digital music once again into a service."243

The same considerations apply to movies. The motion picture industry was in its infancy when The Castaway hit bookstores. For many decades thereafter, the only way to experience a movie was to wait until it came to one's local cinema, or later when a local television station carried its broadcast. ${ }^{244}$ The situation changed only with the advent of the Betamax in the 1970s.

We can therefore appreciate that, before high-fidelity music recording and videotape recording capabilities, users had none of the privileges

241. See supra text accompanying note 101.

242. See generally Fred Hoyle, THE Black Cloud (William Heinemann Ltd. ed., 1957) (positing intelligence circling earth in a cloud that blocks out the sun).

243. Jay Anderson, Stream Capture: Returning Control of Digital Music to the Users, 25 HARV. J.L. \& TECH. 159, 162 (2011).

244. See David Nimmer, Brains and Other Paraphernalia of the Digital Age, 10 HARV. J.L. \& TECH. 1, 14-16 (1996). 
canonized above. During those intervals, they had no ability to obtain ownership of songs or movies; instead, they had to wait for others to perform them. In addition, they certainly enjoyed no "essential step" defense in that context. And their rights of fair use were also extremely circumscribed, given no practical way of quoting at length from the music and movies that had been evanescently performed and then passed into the ether. ${ }^{245}$

Viewed from this perspective, the cloud simply returns music to its origins, ${ }^{246}$ and the same for film too. By replacing products with streams, the cloud brings back to the fore the effective copyright status of large swaths of works that existed for many decades in the past.

If the enjoyment of movies in the 2030s matches that of the 1930s-in which the proprietor could make a charge for each and every viewing ${ }^{247}$ - no cosmic injustice requires redress. Instead, the long eye of history can take bemusement in the swirls and eddies of time, in which nothing is really new under the sun.

\section{Highs And Lows in TURbulent Transitions}

Whatever the long-term weather forecast may hold for clouds, there is one prediction which we do not hesitate to make at this juncture: there will be turbulent transitions. ${ }^{248}$ Software in the cloud places entirely different pressure points on copyrights than software on desktops. Phases of high pressure will alternate with low-pressure systems moving in as the marketplace, technological measures, courts, and perhaps even legislatures adjust. But any future envisioned today will inevitably be upset by tomorrow's reality. We have no choice but to live and learn.

245. As to movies, there was no practical way to "perform" them at home. As to music, by contrast, anyone with the requisite skill was welcome to play the tune on the living room piano. Presumably, even a neighborhood gathering to sing familiar tunes would enjoy a robust fair use defense.

246. "Music began as a service and has remained exclusively so for most of its existence. Until very recently in human history, a person wishing to hear music required the performance of a musician." Anderson, supra note 243, at 162.

247. In the twentieth century, the charge from the studios was either to theaters or to broadcast networks. In the current century, the charge will be directly to consumers-to whom the charge was previously passed on by those intermediaries.

248. High honors go here to the prospects of cloud purveyors offering proprietary software without authorization to thousands of remote users, as discussed above. See supra Section III.C. 
